MARIANA GRANZIERA SPOLIDORIO

\title{
Perfil sorológico e molecular de zoonoses transmitidas por carrapatos em humanos e animais domésticos oriundos de seis municípios do Estado do Espírito Santo
}

Tese apresentada à Faculdade de Medicina da Universidade de São Paulo para obtenção do título de Doutora em Ciências

Área de concentração: Reumatologia Orientador: Prof. Dr. Natalino Hajime Yoshinari

São Paulo 2009 
"A persistência é o caminho do êxito"

Charlie Chaplin 
Dados Internacionais de Catalogação na Publicação (CIP)

Preparada pela Biblioteca da

Faculdade de Medicina da Universidade de São Paulo

Creprodução autorizada pelo autor

Spolidorio, Mariana Granziera

Perfil sorológico e molecular de zoonoses transmitidas por carrapatos em humanos e animais domésticos oriundos de seis municípios do Estado do Espírito Santo / Mariana Granziera Spolidorio. -- São Paulo, 2009.

Tese(doutorado)--Faculdade de Medicina da Universidade de São Paulo. Departamento de Clínica Médica.

Área de concentração: Reumatologia.

Orientador: Natalino Hajime Yoshinari

Descritores: 1.Carrapatos 2.Zoonoses 3.Epidemiologia 4.Rickettsia 5.Doença de Lyme

USP/FM/SBD-385/09 
Dedico esta tese com todo o meu amor à minha avó Vera, que sempre se orgulhou desta neta, acreditou no meu potencial e, de longe, está muito feliz em ver este trabalho ser finalizado honradamente. 


\section{AGRADECIMENTOS}

Ao meu orientador, Dr. Natalino, pela grande oportunidade, ensinamentos durante estes 5 anos, sendo estes não só para a vida profissional, mas também pessoal, pela orientação e pela paciência.

Ao meu "pseudo-orientador" e amigo, Marcelo B. Labruna, pela amizade, apoio, exemplo de caráter, ensinamentos e conselhos dados ao longo do desenvolvimento deste trabalho.

\section{Aos amigos da FM-USP;}

À amiga Elenice, pelo companheirismo e amizade nestes mais de 5 anos de convivência.

À Virginia, pelos ensinamentos essenciais no inicio de tudo, convivência e amizade. Aos amigos Mayra, Guilherme, Anderson e Roberta, pelos bons momentos compartilhados e pelo apoio no decorrer do trabalho.

As amigas secretárias: Fátima, Marta, Cláudia e Iná, pela paciência, apoio logístico e amizade.

A Dra. Eloísa, pela oportunidade de ingressar na Reumatologia FMUSP.

A todas as amigas (e amigos) da Reumato FMUSP, que sempre estiveram dispostos a me ajudar sempre que precisei. 


\section{Aos amigos da FMVZ-USP;}

Jonas, pelos bons momentos de risada e de trabalho, por me auxiliar na realização das RIFIs e pela amizade.

Richard, pelos ensinamentos diversos na prática laboratorial e pelos ótimos momentos de distração.

Maurício, quando ainda estava no VPS, por toda a amizade e incentivo no decorrer do trabalho.

Maria, pela amizade polonesa mais transparente e verdadeira e pelos ótimos momentos de descontração.

Thiago, pelo auxilio e ensinamentos na identificação de carrapatos, pela amizade e confiança.

A todos os amigos do Laboratório de Parasitologia (Carrapatos), por todos os ótimos momentos de descontração, congressos, pelos sorrisos e momentos inesquecíveis. A todos os amigos do VPS.

\section{Aos amigos do Espírito Santo;}

Augusto, Késia, Dirlei e Regina, pela essencial colaboração, apoio logístico, companheirismo e momentos de descontração durante as viagens ao ES para coleta de material.

A todos os colaboradores do LACEN Vitória, SESA Colatina e SVS Nova Venécia.

\section{Aos amigos da UNESP Campus Jaboticabal;}

A querida Profa. Rosangela Z. Machado, pelo apoio no projeto, confiança, ensinamentos, abertura dada e carinho. 
A todos os alunos e funcionários do laboratório.

Ao Laboratório Paddock, por me ceder as amostras negativas de equinos para padronização de ensaios.

À médica veterinária Dra. Layla, pelas amostras negativas de cães cedidas gentilmente.

Aos meus queridos pais, por todo o amor, pela minha criação, por estarem ao meu lado em todos os momentos, acreditando e incentivando cada passo dado com o maior orgulho do mundo. Amo vocês.

Ao meu amor, Victor (Xuxu), por ser um anjo em minha vida, me encorajar, me apoiar em todas as decisões, dividir comigo minhas angústias, me escutar e aconselhar, e por todo o amor que existe entre nós.

Aos meus avós Alice e Augusto, pelo carinho, por se orgulharem e acreditarem em mim sempre, por serem muito importantes na minha vida.

A todos os demais familiares sempre presentes na minha vida, pelo apoio. 


\section{Aos meus grandes amigos;}

Vinicius, por estar ao meu lado sempre, mesmo quando está fisicamente longe, por me ensinar e dividir experiências, e por ser o responsável indiretamente por me fazer ingressar na FMUSP.

Às minhas "irmãs" Débora, Michelle e Bettina, pela enorme amizade, por me ouvirem nas horas de desespero e me aconselharem, por sempre me incentivarem e por acreditarem em mim sempre.

A todos os meus amigos, por me proporcionarem tantos momentos de descontração e alegria. Amo vocês!

Ao Ministério da Saúde (CGLAB), principalmente a Denise M. Mancini, quem tornou possível as viagens para coleta de materiais no ES, sem os quais essa tese não existiria.

À FAPESP, pelo apoio financeiro ao projeto, e à CAPES, pela bolsa de Doutorado Direto.

A todos que sempre me apoiaram e deram forças até o fim deste trabalho.

Ao "algo" maior, que sempre iluminou o meu caminho... 


\section{SUMÁRIO}

Lista de abreviaturas

Resumo

Summary

1. OBJETIVOS

02

2. ARTIGO SUBMETIDO AO PERIÓDICO “American Journal of Tropical Medicine and Hygine", entitulado "Survey for tick-borne Zoonoses in the State of Espirito Santo, southeastern Brazil”, VERSÃO EM PORTUGUÊS 04

3. ARTIGO PUBLICADO NO PERIÓDICO "Veterinary Parasitology", Entitulado "Hepatozoon canis infecting dogs in the State of Espírito Santo, southeastern Brazil”, VERSÃO EM PORTUGUÊS 28

4. CONCLUSÕES 44

ANEXO 1: Comprovante de submissão do artigo "Survey for tick-borne zoonoses in the State of Espirito Santo, southeastern Brazil" ao periódico "American Journal of Tropical Medicine and Hygine". 47

ANEXO 2: Artigo publicado no periódico "Veterinary Parasitology". 69 


\section{LISTA DE ABREVIATURAS}

SBY

BYS

FMB

DL

ZTC

PCR
- Síndrome Baggio-Yoshinari

- Baggio-Yoshinari Syndrome

- Febre Maculosa Brasileira

- Doença de Lyme

- Zoonose transmitida por carrapatos

- Polymerase Chain Reaction 


\section{RESUMO}

Spolidorio, MG. Perfil sorológico e molecular de zoonoses transmitidas por carrapatos em humanos e animais domésticos oriundos de seis municípios do Estado do Espírito Santo [tese]. São Paulo: Faculdade de Medicina, Universidade de São Paulo: 2009.

O estudo objetivou realizar um levantamento de doenças transmitidas por carrapatos em amostras de humanos e animais domésticos oriundos do Estado do Espírito Santo. Foram estudadas as Riquétsioses, Erliquiose, Babesiose, Borreliose, e especificamente em cães a Hepatozoonose canina. Três expedições científicas foram realizadas, onde foram coletadas amostras de sangue de humanos $(n=201)$, cães ( $n=92)$ e eqüídeos $(n=27)$. As amostras foram testadas utilizando-se os ensaios de Imunofluorescência Indireta (RIFI) e ELISA Indireto, dependendo do antígeno de eleição. A Reação em Cadeia de Polimerase (PCR) foi realizada utilizando primers específicos para os gêneros dos agentes pesquisados. Foi possível concluir que os municípios estudados podem ser considerados endêmicos para as zoonoses pesquisadas.

Descritores: Carrapatos, zoonoses, epidemiologia, Rickettsia, Doença de Lyme 


\section{SUMMARY}

Spolidorio, MG. Serological and molecular profile of tick-borne diseases in humans and domestic animals from six municipalities in the State of Espirito Santo [thesis]. São Paulo: "Faculdade de Medicina, Universidade de São Paulo"; 2009.

This study aimed to perform a survey on tick-borne diseases in blood samples from humans and domestic animals from the State of Espírito Santo. The following diseases were studied: Rickettsiosis, Ehrlichiosis, Babesiosis, Borreliosis, and specifically in dogs, Canine Hepatozoonosis. Three scientific expeditions were performed, where blood samples from humans $(n=201)$, dogs $(n=92)$ and equids $(n=27)$ were collected. Samples were tested using Indirect Immunofluorescence Assays (IFA) and Indirect ELISA, depending on the antigen. Polymerase Chain Reactions (PCR) were performed using specific primers to the genera of the surveyed agents. We concluded that the studied municipalities can be considered endemic areas to the surveyed zoonosis.

Descriptors: ticks, zoonosis, epidemiology, Rickettsia, Lyme Disease 
1. OBJETIVOS 
Este trabalho teve como objetivo principal traçar um perfil epidemiológico das principais zoonoses transmitidas por carrapatos (ZTCs) nos municípios estudados pertencentes, em sua maioria, à região norte do Estado do Espírito Santo.

Também foi possível, paralelamente, padronizar técnicas diagnósticas de biologia molecular e sorologia para as diferentes doenças estudadas, para amostras de sangue de humanos. 
2. ARTIGO SUBMETIDO À American Journal of Tropical Medicine and Hygine, EM PORTUGUÊS 


\section{Pesquisa por zoonoses transmitidas por carrapatos no Estado do Espírito Santo,} sudeste do Brazil

Mariana G. Spolidorio, Marcelo B. Labruna, Rosangela Z. Machado, Jonas MoraesFilho, Augusto M. Zago, Dirlei M. Donatele, Iara Silveira, Késia M. Caliari, Natalino H. Yoshinari

Laboratório de Investigação Médica 17 (LIM17), Faculdade de Medicina, Universidade de São Paulo, São Paulo, Brazil; Departamento de Medicina Veterinária Preventiva e Saúde Animal, Faculdade de Medicina Veterinária e Zootecnia, Universidade de São Paulo, São Paulo, Brazil; Departamento de Patologia Veterinária, Faculdade de Ciências Agrárias e Veterinárias, Universidade Estadual Paulista “Julio de Mesquita Filho”, Jaboticabal, Brazil; Núcleo de Vigilância em Saúde, Superintendência Regional de Saúde de Colatina, Colatina, Espírito Santo, Brazil;Centro Universitário São Camilo Espírito Santo, Cachoeiro de Itapemirim, Espírito Santo, Brazil.

\section{RESUMO}

Amostras de sangue coletadas de 201 humanos, 92 cães, e 27 equinos no Estado do Espírito Santo, Brasil, foram testados pela Reação em Cadeira de Polimerase (PCR), reação de imunofluorescência indireta (RIFI), e ELISA Indireto para doenças transmitidas por carrapatos (riquetsioses, erliquiose, anaplasmose, borreliose, babesiose). Nossos resultados indicaram que as regiões estudadas são endêmicas para as riquetsioses do grupo da febre maculosa porque o soro de 70 
(34.8\%) humanos, $7(7.6 \%)$ cães, e $7(25.9 \%)$ equinos foram reagentes para ao menos uma das seis espécies de Rickettsia testadas. Houve evidencia de erliquiose (Ehrlichia canis) e babesiose (Babesia canis vogeli, Theileria equi) em animais domésticos, e em humanos, apenas 4 foram sorologicamente positivos para E. canis e nenhum para babesiose. Sorologia positiva para Borrelia burgdorferi foi raro em humanos e equinos, porém esteve elevada em cães $(51,1 \%)$, indicando possível participação destes animais e carrapatos no ciclo epidemiológico da doença Brasileira, nomeada Síndrome Baggio-Yoshinari.

\section{INTRODUÇÃO}

A Febre Maculosa Brasileira (FMB), uma riquetsiose causada por Rickettsia rickettsii, é a doença transmitida por carrapato mais prevalente no Brasil, onde seus primeiros relatos datam da década de $30 .{ }^{1,2}$ Os Estados da região sudeste brasileira (São Paulo, Minas Gerais, Rio de Janeiro e Espírito Santo) são considerados endêmicos para FMB, embora a maioria dos estudos tenham sido conduzidos nos primeiros três Estados, com somente dois estudos relatados no Estado do Espírito Santo. $^{3-8}$

A Síndrome da Doença de Lyme-símile é uma entidade clínica emergente que tem sido descrita no Brasil, que mimetiza as manifestações clínicas da Doença de Lyme clássica encontrada no hemisfério Norte. Entretanto, espiroquetas não foram identificadas em pacientes brasileiros e carrapatos, apesar da exaustiva utilização de métodos moleculares e microbiológicos em amostras clínicas. ${ }^{9}$ A nomenclatura da doença brasileira foi renomeada para Síndrome Baggio-Yoshinari (SBY) durante o 
Encontro Paulista de Reumatologia de 2005, em São Paulo, propondo a ocorrência de uma nova zoonose transmitida por carrapatos no país, diferente da Doença de Lyme, possivelmente causada por espécies diferentes ou modificadas de espiroquetas (NHY, dados não publicados).

A erliquiose monocítica canina, causada por Ehrlichia canis, é a doença transmitida por carrapatos mais importante em cães no Brasil. E. canis é atualmente a unica espécie de Ehrlichia que tem sido isolada de vertebrados na América do Sul. ${ }^{10-}$ ${ }^{12}$ Uma investigação preliminar de espécies de Ehrlichia foi desenvolvida nas regiões Norte e Sudeste do Brasil, incluindo varias espécies de carrapatos, humanos, cães, e capivaras, mas não foi encontrado DNA de Ehrlichia em amostras humanas. ${ }^{13}$ Diferentemente, DNA de Ehrlichia compatível com Ehrlichia chaffeensis e Ehrlichia ewingii foi recentemente relatado em amostras de sangue animal no Brasil. ${ }^{14,15}$ Casos humanos de erliquiose no Brasil foram relatados somente por suspeitas clínicas e testes sorológicos, sem amplificação de DNA e identificação do agente. ${ }^{16,17}$

A Babesiose é uma doença transmitida por carrapatos comum em cães e equinos no Brasil. Babesia canis vogeli $(=$ B. vogeli) é o agente mais comum afetando os cães, embora tenham alguns relatos de Babesia gibsoni. ${ }^{18-21}$ A Babesiose em equinos é causada principalmente por Babesia caballi e Theileria equi (anteriormente Babesia equi), as quais são endêmicas nos trópicos, subtrópicos e parcialmente em zonas temperadas. ${ }^{22}$ No hemisfério Norte, a babesiose humana é encontrada nos Estados Unidos da América, onde três espécies diferentes ocorrem, e também na Europa, onde as principais espécies identificadas em humanos são $B$. divergens, B. microti e B. odocolei. ${ }^{23-25}$ A América do Sul tem poucos relatos de babesiose humana, incluindo o primeiro caso suspeito descrito no Estado de 
Pernambuco, estudo sorológico realizado na Colômbia, um caso descrito na Polônia mas aparentemente contraído no Brasil, ocorrência de anticorpos anti-Babesia em pacientes com Doença de Lyme símile brasileira, e um caso de uma criança com hepatoblastoma e esfregaço sanguíneo positivo que sugeriu infecção por Babesia. ${ }^{26-30}$

Com o objetivo de investigar zoonoses transmitidas por carrapatos e estabelecer a epidemiologia destas doenças na região Norte do Estado do Espírito Santo, visitamos seis localidades nesta área, e desenvolvemos sorologia e biologia molecular para as doenças transmitidas por carrapatos mais comuns em humanos e animais domésticos no Brasil. Estas localidades foram selecionadas devido ao recente histórico de casos confirmados laboratorialmente de FMB, incluindo casos fatais (dados não publicados da Secretária da Saúde do Estado do Espírito Santo), e/ou grande número de pacientes com SBY (NHY, dados não publicados).

\section{MATERIAIS E MÉTODOS}

Este estudo amostrou humanos, cães, e equinos residentes em 23 localidades em áreas rurais e urbanas dentro de 6 municípios localidades no Estado do Espírito Santo, Brasil: Nova Venécia, São Mateus, Santa Leopoldina, Ecoporanga, Colatina, e Vila Valério (Figura 1). Amostras foram coletadas de Maio de 2007 a Março de 2008 durante três expedições científicas no Estado do Espírito Santo. Em cada expedição, fazendas em áreas rurais e residências em localidades urbanas foram visitadas com o intuito de coletarmos amostras de sangue de humanos, cães, e eqüinos. Nenhum dos indivíduos selecionados apresentava sinais clínicos de doenças infecciosas agudas quando o sangue foi coletado. Um total de 109 humanos, 85 cães, e 24 equinos foram 
coletados de 22 localidades (17 fazendas e 5 residências). Adicionalmente, 92 humanos, 7 cães, e 3 equinos foram amostrados em uma Escola Agro-Técnica localizada na área rural do município de Colatina. A coleta de amostras de sangue de animais e humanos foi previamente aprovada pela Comissão de Ética para Projetos de Pesquisa (CAPPesq), Faculdade de Medicina, Universidade de São Paulo. Quatro das localidades rurais tiveram casos humanos de FMB (supostamente causadas por R. rickettsii) confirmados durante 2003-2005 com ao menos 4 casos fatais (dados não publicados da Secretaria de Saúde do Estado do Espírito Santo). As 18 localidades restantes foram consideradas de risco para a Síndrome Doença de Lyme-símile (= Síndrome Baggio-Yoshinari), pelo grande volume de amostras de soros positivos para Borrelia burgdorferi, encaminhados ao Laboratório de Referência no estuda da SBY, Faculdade de Medicina da Universidade de São Paulo, provenientes destas áreas. Amostras de sangue foram coletadas em dois tubos: um com anticoagulante (EDTA), mantidas congeladas a $-20^{\circ} \mathrm{C}$ até a extração de DNA; e o outro sem EDTA, do qual o soro foi separado por centrifugação e mantido congelado até serem testados por métodos sorológicos.

Extração de DNA e Reação em Cadeia de Polimerase (PCR). DNA foi extraído de cada amostra de sangue utilizando-se o kit DNeasy Blood \& Tissue Kit (Qiagen, Hilden, Germany), de acordo com as instruções do fabricante. As amostras de DNA foram eluídas em100 mL de tampão TE. Água livre de DNA foi utilizada como controle negativo das extrações. Cinco microlitros do DNA extraído foram utilizados na amplificação pela reação em cadeia de polimerase (PCR). As amostras foram individualmente testadas por uma bateria de PCR utilizando os protocolos descritos abaixo. 
Os primers GE2 (5` - GTT AGT GGC AGA CGG GTG AGT - 3`) e HE3 (5`- TAT AGG TAC CGT CAT TAT CTT CCC TAT - 3`) foram utilizados para amplificar um fragmento de $360 \mathrm{pb}$ do gene $16 \mathrm{~S}$ rRNA de Anaplasmataceae. ${ }^{31-33} \mathrm{~A}$ PCR foi realizada em uma solução total de $50 \mu \mathrm{L}$ contendo $1 \mathrm{X}$ PCR buffer desprovido de $\mathrm{Mg}, 1.5 \mathrm{mM} \mathrm{MgCl}, 0.2 \mathrm{mM}$ dNTPs, $1 \mathrm{U}$ de Platinum TaqDNA Polymerase (Invitrogen, Carlsbad, CA), e $0.2 \mu \mathrm{M}$ de cada primer. As condições dos ciclos de PCR consistiram em uma denaturação inicial por 5 min a $95^{\circ} \mathrm{C}$, e 40 ciclos repetitivos de $15 \mathrm{seg}$ a $95^{\circ} \mathrm{C}, 30 \mathrm{seg}$ a $62^{\circ} \mathrm{C}$, e $30 \mathrm{seg}$ a $72^{\circ} \mathrm{C}$, seguidos por 7 min de extensão final a $72^{\circ} \mathrm{C}$. Controle positivo (DNA previamente conhecido proveniente de cão infectado por $E$. canis) e controle negativo (água) foram incluídos em todos os ensaios de PCR.

Para amplificar um fragmento de $665 \mathrm{pb}$ do gene de flagelina de Borrelia (flaB), a reação inicial de PCR utilizando primers FLA LL (5'- ACA TAT TCA GAT GCA GAC AGA GGT - 3') e FLA RL (5'-GCA ATC ATA GCC ATT GCA GAT TGT - 3') foram empregados, e para a nested-PCR que amplifica um fragmento de 354-pb, primers FLA RS (5 - CTT TGA TCA CTT ATC ATT CTA ATA GC - 3`) e FLA LS (5`- AAC AGC TGA AGA GCT TGG AAT G - 3`) foram utilizados, com pequenas modificações. ${ }^{34}$ A PCR foi realizada em uma solução total de $50 \mu \mathrm{L}$ contendo $1 \mathrm{X}$ PCR buffer desprovido de $\mathrm{Mg}, 1.5 \mathrm{mM} \mathrm{MgCl} 2,0.2 \mathrm{mM}$ dNTPs, 1 U de Platinum TaqDNA Polymerase (Invitrogen, Carlsbad, CA), e $0.2 \mu \mathrm{M}$ de cada primer. Para todas as reações de PCR, um controle positivo (DNA extraído de cultura de Borrelia anserina) e dois controles negativos (água) foram incluídos. Os ciclos de temperatura para ambas as reações incluíram uma denaturação inicial de 
$3 \min$ a $95^{\circ} \mathrm{C}$, e 40 ciclos repetitivos de $1 \min$ a $95^{\circ} \mathrm{C}, 1 \min$ a $65^{\circ} \mathrm{C}$, e 1 min a $75^{\circ} \mathrm{C}$, seguidos por uma extensão final de $10 \min$ a $75^{\circ} \mathrm{C}$.

PCR para identificar Babesia spp foi realizada utilizando os primers BAB-3357 (5'- GCC AGT AGT CAT ATG CTT GTC TTAA -3') e BAB-432-409 (5’' TTC CTT AGA TGT GGT AGC CGT TTC -3'), correspondentes a regiões conservadas do gene 18S rRNA de Babesia spp, desenvolvidos para amplificar uma porção de ₹370-pb deste gene. A PCR foi realizada em uma solução total de $50 \mu \mathrm{L}$ contendo $1 \mathrm{X}$ PCR buffer desprovido de $\mathrm{Mg}, 1.5 \mathrm{mM} \mathrm{MgCl}_{2}, 0.2 \mathrm{mM}$ dNTPs, $1 \mathrm{U}$ de Platinum TaqDNA Polymerase (Invitrogen, Carlsbad, CA), e $0.2 \mu \mathrm{M}$ de cada primer. Um controle positivo (DNA de um cão infectado por B. canis previamente conhecido) e controles negativos (água) foram incluídos em todos os ensaios de PCR. Os ciclos de temperatura da PCR consistiram de uma denaturação inicial por 3 min a $95^{\circ} \mathrm{C}$, e 40 ciclos repetitivos de 15 seg a $95^{\circ} \mathrm{C}, 30 \mathrm{seg}$ a $63^{\circ} \mathrm{C}$, e 30 seg a $72^{\circ} \mathrm{C}$, seguidos de uma extensão final de 7 min a $72^{\circ} \mathrm{C}$. As amostras positivas nas PCRs foram purificadas utilizando ExoSap (USB) e seqüenciadas em seqüenciador automático (Applied Biosystems/PerkinElmer, modelo ABI Prism 310 Genetic, CA, US) de acordo com as instruções dos fabricantes. As seqüências parciais obtidas foram submetidas à análise BLAST para determinar a similaridade com outras espécies. ${ }^{35}$

ELISA indireto para B. burgdorferi. A preparação do antígeno foi desenvolvida como previamente descrita. ${ }^{36}$ O ELISA indireto utilizando antígeno de B. burgdorferi $\mathrm{G} 39 / 40$, origem Norte-americana, foi realizado pelo método padrão com pequenas modificações para as amostras humanas, e exatamente como descrito quando realizado em amostras de soro dos cães. ${ }^{36,37}$ IgG anti-cão conjugado com Fosfatase Alcalina produzido em coelho (Sigma-Aldrich, St. Louis, MO) foi 
adicionado em uma diluição de 1:1000 em solução de bloqueio. $O$ soro de 8 cães provenientes de área urbana de São Paulo, sem histórico de picada por carrapatos e sem terem feito visitas a áreas rurais foram utilizados como controles negativos. Como controle positivo da reação, um soro positivo de cão previamente conhecido foi empregado. $\mathrm{O}$ mesmo método foi aplicado às amostras de soros humanos, mas neste caso tanto $\operatorname{IgG}$ como IgM foram testados como descritos previamente. ${ }^{38} \operatorname{IgG}$ anti-humano e IgM anti-humano, ambos conjugados com Fosfatase Alcalina (Sigma) foram diluídos 1:1000 em solução de bloqueio. Oito amostras negativas de soros humanos provenientes de pessoas que não relataram picada por carrapatos e não apresentavam enfermidades foram utilizados como controles negativos. Como controle positivo, um soro humano conhecidamente positivo para antígeno de $B$. burgdorferi foi utilizado.

O ELISA indireto para soros de eqüinos foi realizado conforme descrito, com pequenas modificações. ${ }^{39}$ Placas foram sensibilizadas com antígeno de $B$. burgdorferi em uma concentração de $15 \mu \mathrm{g} / \mathrm{mL}$ diluído em tampão Carbonato $(\mathrm{pH}=9,6)$. Tween $80(0.05 \%)$ foi empregado ao contrario de Tween 20 . Tampão de bloqueio foi preparado com 5\% de leite desnatado diluído em PBS Tween 80 $(\mathrm{pH}=7.4)$. Todas as amostras de soro (incluindo os oito controles negativos) foram utilizados na diluição de 1:400, e o controle positivo foi titulado realizando-se diluição seriada, iniciando em 1:400. IgG Anti-cavalo conjugada com Fosfatase Alcalina (Sigma) foi diluída 1:15000 em tampão PBS Tween 80, e as placas foram incubadas por 60 min em câmara úmida á temperatura ambiente. Depois, procedimentos de lavagem foram empregados e o substrato foi aplicado como previamente descrito. As placas foram lidas a $405 \mathrm{~nm}$ no leitor Titertek Multiscan 
MCC/340 (Flow Laboratories), e quando a primeira diluição do controle positivo atingiu a densidade óptica próxima de 1.0, a reação estava pronta para a leitura. $\mathrm{O}$ ponto de corte foi estabelecido com grau de confiança de 99.9\%, obtido considerando-se a densidade óptica somada a três vezes o desvio padrão dos oito controles negativos. As densidades ópticas maiores do que o ponto de corte foram consideradas positivas e os títulos foram estimados por uma curva de regressão.

Reação de Imunofluorescência Indireta (RIFI) para Rickettsia spp. As lâminas de RIFI foram preparadas utilizando-se lâminas de 12 poços contendo antígenos brutos derivados de seis isolados de Rickettsia do Brasil: R. rickettsii cepa Taiaçu, $R$. parkeri cepa At24, $R$. bellii cepa Mogi das Cruzes, $R$. amblyommii cepa Ac37, $R$. rhipicephali cepa HJ5 e $R$. felis cepa Pedreira. As lâminas foram preparadas como descritas previamente. ${ }^{40}$ Soros humanos, caninos e de eqüinos foram diluídos em diluição seriada com PBS iniciando na diluição 1:64. Dez microlitros do soro diluído foram adicionados em cada poço de cada lâmina. As lâminas foram incubadas a $37^{\circ} \mathrm{C}$ por 30 minutos em câmara úmida. As lâminas foram enxaguadas uma vez, e então lavadas duas vezes por 10 minutos por lavagem em PBS. A incubação das lâminas foi feita com IgG anti-humano conjugado com fluoresceína produzido em cabra, IgG anti-cão produzido em cabra ou IgG anti-cavalo produzido em cabra (IgG; Sigma Diagnostics, St. Louis, MO), e lavadas como descritas acima. As lâminas foram montadas com glicerina tamponada sob lamínula. Em cada lâmina, um soro negativo previamente conhecido (controle negativo) e um soro reativo conhecido (controle positivo) foram testados. Para cada amostra, o ponto de corte da reação para cada um dos seis antígenos de Rickettsia foi determinado. As lâminas 
foram lidas em microscópio de luz ultravioleta (Olympus BX60, Japan) em um aumento de 400X.

RIFI para Ehrlichia canis. Amostras de soros individuais foram testadas utilizando-se como antígeno células DH82 infectadas com E. canis, realizado com uma cepa brasileira (cepa São Paulo) isolada de um cão naturalmente infectado. ${ }^{12}$ IgG anti-cão conjugado com fluoresceína (Sigma) previamente titulado para a melhor diluição de trabalho (1:600) foi utilizado como descrito. ${ }^{12,41}$ Para os soros humanos, IgG anti-humano conjugado com fluoresceína (Sigma) foi empregado na diluição 1:400. O soro foi considerado como contendo anticorpos reativos a E. canis se ele demonstrasse reação positiva na diluição 1:64. Uma solução de bloqueio (BSA $1 \%$ em PBS para soros de cão, e soro de coelho inativado diluído 2\% em PBS para soros humanos) foi utilizada para diminuir a reação de fundo. Em cada lâmina, um soro não reativo previamente conhecido (controle negativo) e um soro conhecidamente positivo (controle positivo) foram testados. As amostras que reagiram na diluição de triagem (1:64) foram tituladas utilizando diluição seriada para determinar o título final da reação.

RIFi para Babesia spp e Theileria equi. Antígenos de Babesia canis, Babesia bovis, e T. equi foram preparados conforme descrito (Furuta PI e colaboradores, Madruga CR e colaboradores, dados não publicados). ${ }^{42}$ Brevemente, as diluição dos soros testados contra Babesia canis foi 1:40, e para B. bovis e T. equi foi 1:80. Após lavagem com tampão PBS, as lâminas foram incubadas com o conjugado fluoresceinado correspondente. IgG anti-cavalo FITC (Sigma) foi diluído 1:32; IgG anti-cão FITC (Sigma) foi diluído 1:200; e IgG anti-humano FITC (Sigma) foi diluído $1: 400 .^{43}$ 


\section{RESULTADOS E DISCUSSÃO}

Os resultados de todos os testes sorológicos e das PCRs realizadas em amostras de sangue de humanos, cães, e equinos estão demonstradas na Tabela 1. Os dados foram separados de acordo com áreas rurais e urbanas. Adicionalmente, os resultados da Escola Agro-Técnica foram apresentados separadamente, pois metade das amostras de humanos coletadas eram provenientes desta localidade.

Todas as amostras humanas foram negativas para Babesia spp, tanto nos testes sorológicos, como na PCR. Raros soros de humanos e equinos foram reagentes para $B$. burgdorferi na sorologia. Por outro lado, aproximadamente metade dos cães foram sorologicamente reagentes para B. burgdorferi, sugerindo que os cães, assim como os carrapatos que infestam estes animais, possam participar do ciclo de transmissão da SBY no Brasil. Ao contrário do descrito nos Estados Unidos da América, Europa e Ásia, carrapatos do complexo Ixodes ricinus não são encontrados nas áreas endêmicas para SBY no país.

Os maiores títulos alcançados para B. burgdorferi nas amostras humanas foram 1:800 para IgG e 1:200 para IgM. No Brasil, as sorologias para B. burgdorferi, mesmo quando positivas apresentam baixos títulos e desaparecem rapidamente. Da mesma forma, espiroquetas jamais foram isoladas das amostras biológicas provenientes de humanos ou de carrapatos. Por estes motivos, a zoonose presente no país, que reproduz os sintomas clínicos exibidos na Doença de Lyme, recebeu a denominação de Síndrome Baggio-Yoshinari. Estudos recentes realizados no Laboratório de Referência para SBY sugerem que o agente etiológico desta Síndrome seja uma espiroqueta modificada nos aspectos genéticos e morfológicos, e 
essas mudanças tenham ocorrido devido a inexistência de carrapatos do complexo Ixodes ricinus nas áreas endêmicas para SBY, biodiversidade de fauna e fatores climáticos do Brasil (NHY, dados não publicados).

Em geral, soro de 70 (34.8\%) humanos, 7 (7.6\%) cães, e 7 (25.9\%) equinos foram reagentes para ao menos uma espécie de Rickettsia. Os títulos finais dos soros humanos variaram entre 64 e 1024 para todas as espécies de Rickettsia. Os títulos finais dos soros de cão variaram entre 64 e 32768 para $R$. rickettsii, 256 e 16384 para R. parkeri, 64 e 4096 para $R$. amblyommii, $R$. rhipicephali, $R$. bellii, e R. felis. Os títulos finais dos soros de equinos variaram entre 64 e 512 para $R$. rickettsii, 64 e 128 para R. parkeri e R. felis, 128 e 1024 para R. amblyommii, e entre 128 e 512 para $R$. rhipicephali e $R$. bellii.

Considerando cada soro individualmente, em todos os casos os títulos finais para duas ou mais espécies de Rickettsia foram menos de 4 vezes maiores do que o menor título obtido, com exceção de um caso, um cão proveniente de uma propriedade de área rural do município de Santa Leopoldina, o qual apresentou título final de 1024 para $R$. felis, 128 para $R$. bellii, e não foi reagente para as demais espécies de Rickettsia. Devido a essa grande diferença entre títulos, a resposta sorológica neste cão foi considerada como sendo causada por $R$. felis. Na verdade, pulgas (Ctenocephalides felis felis) infectadas por $R$. felis coletadas em cães foram observadas tanto em áreas urbanas como em áreas rurais do presente estudo (Labruna MB e colaboradores, dados não publicados). Estes resultados sugerem que parte dos soros humanos reagentes neste estudo podem indicar uma infecção passada por $R$. felis. 
Os resultados sorológicos, agrupados com os ensaios moleculares, indicam que uma quantidade significativa de cães estava infectada por E. canis. Embora nenhuma amostra de sangue humano tenha demonstrado a presença de DNA de Ehrlichia, ao menos $2 \%$ dos soros humanos foram reagentes ao antígeno de E. canis pela RIFI. Visto que E. canis tem sido vista infectando humanos na Venezuela, estas respostas sorológicas à E. canis no presente estudo podem representar uma infecção acidental por E. canis, já que carrapatos $R$. sanguineus foram comumente encontrados em cães das localidades tanto em áreas urbanas, como em áreas rurais deste estudo. ${ }^{44,45}$

Para a maioria dos agentes investigados, resultados semelhantes foram encontrados em áreas urbanas e rurais em amostras de humanos e cães. É possível que estes resultados sejam vistos como inesperados devido ao fato de as áreas urbanas e rurais apresentarem muitas diferenças ecológicas, embora em todos os municípios selecionados, a separação das áreas urbanas das rurais seja muito tênue. Entretanto, todas as localidades urbanas do presente estudo foram selecionadas pelo recente histórico de Síndrome da Doença de Lyme-símile entre os moradores. Neste caso, todos eles relataram ataque por carrapatos previamente quando visitaram áreas rurais (dados não demonstrados).

Tanto as amostras humanas como as amostras de equinos provenientes da Escola Agro-Técnica revelaram reações sorológicas positivas para as seis espécies de Rickettsia, contrastando com as amostras de cães que não mostraram reatividade. Em 2005, a morte de dois humanos na escola foi assumida como sendo causadas por uma Rickettsia do Grupo da Febre Maculosa Brasileira (GFMB) (dados não publicados da Secretaria de Saúde do Estado do Espírito Santo). A maioria das pessoas da escola, 
amostradas neste estudo, relatou picada por carrapatos, na escola ou na sua vizinhança. Parte destes carrapatos foi coletada, e estes foram identificados como Amblyomma cajennense e Amblyomma dubitatum (dados não demonstrados). Possivelmente, os poucos cães amostrados na escola são menos expostos a estes carrapatos, visto que eles eram mantidos próximos aos prédios principais da escola, e longe dos campos infestados por carrapatos onde os alunos regularmente tinham aulas práticas e os equinos eram utilizados em trabalhos de campo.

Reunindo nossos resultados, podemos inferir que a região Norte do Estado do Espírito Santo pode ser considerada uma área endêmica para Rickettsia do GFMB, mas nenhuma outra consideração pode ser feita sobre os outros organismos levando em consideração a população humana. Contudo, em relação aos animais domésticos, concluímos que Ehrlichia canis e Babesia spp. estavam circulantes nas localidades pesquisadas, contribuindo para predizer que estas áreas são endêmicas para algumas doenças transmitidas por carrapatos em animais. Hepatozoon canis também foi encontrado infectando cães, como previamente descrito. ${ }^{45}$ Estudos futuros utilizando este exemplo de pesquisa em outras partes do Brasil contribuirão para melhor elucidar estas zoonoses transmitidas por carrapatos.

Agradecimentos: Somos gratos a Melanie Gutjahr (Laboratório de Epidemiologia da Faculdade de Medicina Veterinária da Universidade de São Paulo) por preparar a Figura 1 do presente estudo, Denise M. Mancini [Coordenação Geral de Laboratórios de Saúde Pública (CGLAB), Secretaria de Vigilância em Saúde (SVS) do Ministério da Saúde (MS)], e Regina M. B. Terrão (Lacen Espírito Santo) pelo apoio logístico no Espírito Santo, e aos "Agentes Locais de Vigilância Ambiental em Saúde do 
Departamento de Vigilância Ambiental do Município de Nova Venécia, ES” pelo auxilio valioso durante os trabalhos de campo.

Apoio Financeiro: Este trabalho teve o apoio da Fundação de Amparo a Pesquisa do Estado de São Paulo (FAPESP apoio 07/51899-2 para N.H.Y.), Coordenação de Aperfeiçoamento de Pessoal de Nível Superior (CAPES bolsa de Doutorado Direto para M.G.S.) e Conselho Nacional de Desenvolvimento Científico e Tecnológico (CNPq bolsa de produtividade para M.B.L.).

\section{REFERENCIAS BIBLIOGRÁFICAS}

1. Dias E, Martins AV, 1939. Spotted fever in Brazil. A summary. Am J Trop Med. 19:103--108.

2. Piza JT, Meyer JR, Gomes LS, 1993. Typho exantematico de São Paulo. São Paulo: Sociedade Impressora Paulista.

3. Galvão MAM, Silva LJ, Nascimento EMM, Calic SB, Sousa R, Bacellar F, 2005. Riquetsioses no Brasil e Portugal: ocorrência, distribuição e diagnóstico. Rev Saúde Pública 39(5): 850--856.

4. Angerami RN, Resende MR, Feltrin AF, Katz G, Nascimento EM, Stucchi RS, Silva LJ, 2006. Brazilian spotted fever: a case series from an endemic area in southeastern Brazil: epidemiological aspects. Ann N Y Acad Sci 1078: 170--172. 
5. Lamas C, Favacho A, Rozental T, Bóia MN, Kirsten AH, Guterres A, Barreira J, de Lemos ER, 2008. Characterization of Rickettsia rickettsii in a case of fatal Brazilian spotted fever in the city of Rio de Janeiro, Brazil. Braz J Infect Dis 12(2): 149--151.

6. Labruna MB, 2009. Ecology of Rickettsia in South America. Ann N Y Acad Sci 1166: 156--166.

7. Sexton DJ, Muniz M, Corey GR, Breitschwerdt EB, Hegarty BC, Dumler S, Walker DH, Pecanha PM, Dietze R, 1993. Brazilian spotted fever in Espirito Santo, Brazil: description of a focus of infection in a new endemic region. Am J Trop Med Hyg 1993 49(2): 222--226.

8. Oliveira KA, Oliveira LS, Dias CC, Silva A Jr, Almeida MR, Almada G, Bouyer DH, Galvão MA, Mafra C, 2008. Molecular identification of Rickettsia felis in ticks and fleas from an endemic area for Brazilian Spotted Fever. Mem Inst Oswaldo Cruz 103(2): 191--194.

9. Mantovani E, Costa IP, Gauditano G, Bonoldi VL, Higuchi ML, Yoshinari NH, 2007. Description of Lyme disease-like syndrome in Brazil. Is it a new tick borne disease or Lyme disease variation? Braz J Med Biol Res 40(4): 443--456.

10. Dumler JS, Barbet AF, Bekker CP, Dasch GA, Palmer GH, Ray SC, Rikihisa Y, Rurangirwa FR, 2001. Reorganization of genera in the families Rickettsiaceae and Anaplasmataceae in the order Rickettsiales: unification of some species of Ehrlichia with Anaplasma, Cowdria with Ehrlichia and Ehrlichia with Neorickettsia, descriptions of six new species combinations and designation of Ehrlichia equi and 'HGE agent' as subjective synonyms of Ehrlichia phagocytophila. Int J Syst Evol Microbiol 51(6): 2145--2165. 
11. Torres HM, Massard CL, Figueiredo MJ, Ferreira T, Almosny NRP, 2002. Isolamento e propagação da Ehrlichia canis em células DH82 e obtenção de antígeno para a reação de imunofluorescência indireta. Rev Bras Ciênc Vet 9: 77-82 .

12. Aguiar DM, Saito TB, Hagiwara MK, Machado RZ, Labruna MB, 2007. Serological diagnosis of canine monocytic ehrlichiosis with Brazilian antigen of Ehrlichia canis. Cienc. Rural 37: 796--802.

13. Labruna MB, McBride JW, Camargo LM, Aguiar DM, Yabsley MJ, Davidson WR, Stromdahl EY, Williamson PC, Stich RW, Long SW, Camargo EP, Walker DH, 2007. A preliminary investigation of Ehrlichia species in ticks, humans, dogs, and capybaras from Brazil. Vet Parasitol 143(2): 189--195.

14. Machado RZ, Duarte JM, Dagnone AS, Szabó MP, 2006. Detection of Ehrlichia chaffeensis in Brazilian marsh deer (Blastocerus dichotomus). Vet Parasitol 139(1-3): 262--266.

15. Oliveira LS, Oliveira KA, Mourão LC, Pescatore AM, Almeida MR, Conceição LG, Galvão MA, Mafra C, 2009. First report of Ehrlichia ewingii detected by molecular investigation in dogs from Brazil. Clin Microbiol Infect Epub ahead of print.

16. Calic SB, Galvão MA, Bacellar F, Rocha CM, Mafra CL, Leite RC, Walker DH., 2004. Human ehrlichioses in Brazil: first suspect cases. Braz J Infect Dis 8(3): 259--262.

17. Costa PS, Valle LM, Brigatte ME, Greco DB, 2006. More about human monocytotropic ehrlichiosis in Brazil: serological evidence of nine new cases. Braz J Infect Dis 10(1): 7--10. 
18. Passos LM, Geiger SM, Ribeiro MF, Pfister K, Zahler-Rinder M, 2005. First molecular detection of Babesia vogeli in dogs from Brazil. Vet Parasitol 127(1): $81--85$.

19. Trapp SM, Messick JB, Vidotto O, Jojima FS, de Morais HS, 2006. Babesia gibsoni genotype Asia in dogs from Brazil. Vet Parasitol 141(1-2): 177--180.

20. Costa-Júnior LM, Ribeiro MF, Rembeck K, Rabelo EM, Zahler-Rinder M, Hirzmann J, Pfister K, Passos LM, 2009. Canine babesiosis caused by Babesia canis vogeli in rural areas of the State of Minas Gerais, Brazil and factors associated with its seroprevalence. Res Vet Sci 86(2): 257--260.

21. O'Dwyer LH, Lopes VV, Rubini AS, Paduan Kdos S, Ribolla PE, 2009. Babesia spp. infection in dogs from rural areas of São Paulo State, Brazil. Rev Bras Parasitol Vet 18(2): 23--26.

22. Friedhoff KT, 1982. Piroplasmas of horses - impact on the international horse trade. Berl Munch Tierarztl Wochenschr 95(19): 368--374.

23. Hildebrandt A, Hunfeld KP, Baier M, Krumbholz A, Sachse S, Lorenzen T, Kiehntopf M, Fricke HJ, Straube E, 2007. First confirmed autochthonous case of human Babesia microti infection in Europe. Eur J Clin Microbiol Infect Dis 26(8): 595--601.

24. Hunfeld KP, Hildebrandt A, Gray JS, 2008. Babesiosis: recent insights into an ancient disease. Int J Parasitol 38(11): 1219--1237. 
25. Herwaldt BL, Cacciò S, Gherlinzoni F, Aspöck H, Slemenda SB, Piccaluga P, Martinelli G, Edelhofer R, Hollenstein U, Poletti G, Pampiglione S, Löschenberger K, Tura S, Pieniazek NJ, 2003. Molecular characterization of a non-Babesia divergens organism causing zoonotic babesiosis in Europe. Emerg Infect Dis (8): 942--948.

26. Alecrim I, Pinto B, Avila T, Costa R, Pessoa I, 1983. Registro do primeiro caso de infecção humana por Babesia spp. no Brasil. Rev Patol Trop 12: 11--29.

27. Ríos L, Alvarez G, Blair S, 2003. Serological and parasitological study and report of the first case of human babesiosis in Colombia. Rev Soc Bras Med Trop 36 (4): 493--498.

28. Humiczewska M, Kuźna-Grygiel W, 1997. A case of imported human babesiosis in Poland. Wiad Parazytol 43(2): 227--229.

29. Yoshinari NH, Abrão MG, Bonoldi VL, Soares CO, Madruga CR, Scofield A, Massard CL, da Fonseca AH, 2003. Coexistence of antibodies to tick-borne agents of babesiosis and Lyme borreliosis in patients from Cotia county, State of São Paulo, Brazil. Mem Inst Oswaldo Cruz 98(3): 311--318.

30. Rech A, Bittar CM, de Castro CG, Azevedo KR, dos Santos RP, Machado AR, Schwartsmann G, Goldani L, Brunetto AL, 2004. Asymptomatic babesiosis in a child with hepatoblastoma. J Pediatr Hematol Oncol 26(3): 213.

31. Anderson BE, Sumner JW, Dawson JE, Tzianabos T, Greene CR, Olson JG, Fishbein DB, Olsen-Rasmussen M, Holloway BP, George EH, 1992. Detection of the etiologic agent of human ehrlichiosis by polymerase chain reaction. J Clin Microbiol 30(4): 775--780. 
32. Breitschwerdt EB, Hegarty BC, Hancock SI, 1998. Sequential evaluation of dogs naturally infected with Ehrlichia canis, Ehrlichia chaffeensis, Ehrlichia equi, Ehrlichia ewingii, or Bartonella vinsonii. J Clin Microbiol 36(9): 2645--2651.

33. Aguiar DM, Hagiwara MK, Labruna MB, 2008. In vitro isolation and molecular characterization of an Ehrlichia canis strain from São Paulo, Brazil. Braz J Microbiol 39: 489-493.

34. Stromdahl EY, Williamson PC, Kollars TM Jr, Evans SR, Barry RK, Vince MA, Dobbs NA, 2003. Evidence of Borrelia lonestari DNA in Amblyomma americanum (Acari: Ixodidae) removed from humans. J Clin Microbiol 41(12): $5557--5562$.

35. Altschul SF, Gish W, Miller W, Myers EW, Lipman DJ, 1990. Basic local alignment search tool. J Mol Biol 215: 403--410.

36. Joppert AM, Hagiwara MK, Yoshinari NH, 2001. Antibodies in dogs from Cotia county, São Paulo State, Brazil. Revta Inst Med Tropical 43(5): 251--255.

37. Voller A, Bidwell DE, Bartlett A, 1976. Enzyme immunoassays in diagnostic medicine. Theory and practice. Bull World Health Organ 53(1): 55--65.

38. Naka EN, Costa IP, Arão CAB, Soares CO, Yoshinari NH, 2008. Pesquisa de anticorpos anti-Borrelia e anti-Babesia em soro de crianças com manifestações clínicas e epidemiologia compatíveis com a doença de Lyme-Simile no Estado de Mato Grosso do Sul. Rev Bras Reumatol 48: 74--85.

39. Salles RS, Fonseca AH, Scofield A, Madureira RC, Yoshinari NH, 2002. Sorologia para Borrelia burgdorferi latu sensu em eqüinos no estado do Rio de Janeiro. Hora Vet 127: 46--49. 
40. Labruna MB, Horta MC, Aguiar DM, Cavalcante GT, Pinter A, Gennari SM, Camargo LM, 2007. Prevalence of Rickettsia infection in dogs from the urban and rural areas of Monte Negro municipality, western Amazon, Brazil. Vector Borne Zoonotic Dis 7(2): 249--225.

41. Ristic M, Huxsoll DL, Weisiger RM, Hildebrandt PK, Nyindo MB, 1972. Serological diagnosis of tropical canine pancytopenia by indirect immunofluorescence. Infect Immun 6(3): 226--231.

42. Baldani CD, Machado RZ, Raso TF, Pinto AA, 2007. Serodiagnosis of Babesia equi in horses submitted to exercise stress. Pesq Vet Bras 27(4): 179--183.

43. Callow LL, McGregor W, Rodwell BJ, Rogers RJ, Fraser GC, Mahoney DF, Robertson GM, 1979. Evaluation of an indirect fluorescent antibody test to diagnose Babesia equi infection in horses. Aust Vet J 55(12): 555--559.

44. Perez M, Bodor M, Zhang C, Xiong Q, Rikihisa Y, 2006. Human infection with Ehrlichia canis accompanied by clinical signs in Venezuela. Ann N Y Acad Sci 1078: 110--117.

45. Spolidorio MG, Labruna MB, Zago AM, Donatele DM, Caliari KM, Yoshinari NH, 2009. Hepatozoon canis infecting dogs in the State of Espírito Santo, southeastern Brazil. Vet Parasitol 163(4): 357--361. 


\section{Tabela 1}

Resultados dos testes sorológicos e PCR realizados em amostras de sangue de humanos, cães, e equinos de seis municípios no Estado do Espírito Santo, Sudeste do Brasil.

\begin{tabular}{|c|c|c|c|c|c|c|c|c|c|c|c|}
\hline \multirow{3}{*}{ Agentes investigados } & \multicolumn{11}{|c|}{ No. De indivíduos que demonstraram positividade (\%) } \\
\hline & \multicolumn{4}{|c|}{ Humanos } & \multicolumn{4}{|c|}{ Cães } & \multicolumn{3}{|c|}{ Equinos } \\
\hline & $\begin{array}{c}\text { Rural } \\
(\mathrm{n}=100)\end{array}$ & $\begin{array}{l}\text { Urbana } \\
(n=9)\end{array}$ & $\begin{array}{l}\text { Escola } \\
(\mathrm{n}=92)\end{array}$ & $\begin{array}{c}\text { Total } \\
(\mathrm{n}=201)\end{array}$ & $\begin{array}{l}\text { Rural } \\
(\mathrm{n}=71)\end{array}$ & $\begin{array}{l}\text { Urbana } \\
(\mathrm{n}=14)\end{array}$ & $\begin{array}{l}\text { Escola } \\
(\mathrm{n}=7)\end{array}$ & $\begin{array}{l}\text { Total } \\
(\mathrm{n}=92)\end{array}$ & $\begin{array}{l}\text { Rural } \\
(\mathrm{n}=24)\end{array}$ & $\begin{array}{l}\text { Escola } \\
(n=3)\end{array}$ & $\begin{array}{l}\text { Total } \\
(\mathrm{n}=27)\end{array}$ \\
\hline \multicolumn{12}{|l|}{ Sorologia } \\
\hline Borrelia burgdorferi & $8(8.0)$ & $1(11.1)$ & $0(0)$ & $9(4.5)$ & $38(53.5)$ & $7(50.0)$ & $2(28.6)$ & $47(51.1)$ & $1(4.2)$ & $0(0)$ & $0(0)$ \\
\hline Rickettsia rickettsii & $31(31.0)$ & $2(22.2)$ & $16(17.4)$ & $49(24.3)$ & $4(5.6)$ & $0(0)$ & $0(0)$ & $4(4.3)$ & $4(16.7)$ & $3(100)$ & $7(25.9)$ \\
\hline R. parkeri & $28(28.0)$ & $2(22.2)$ & $21(22.8)$ & $41(20.4)$ & $2(2.8)$ & $0(0)$ & $0(0)$ & $2(2.2)$ & $2(8.3)$ & $2(66.7)$ & $4(14.8)$ \\
\hline R. amblyommii & $33(33.3)$ & $3(33.3)$ & $16(17.4)$ & $52(25.9)$ & $3(4.2)$ & $0(0)$ & $0(0)$ & $3(3.3)$ & $3(2.5)$ & $2(66.7)$ & $5(18.5)$ \\
\hline R. rhipicephali & $36(36.0)$ & $4(44.4)$ & $17(18.5)$ & $57(28.3)$ & $2(2.8)$ & $1(7.1)$ & $0(0)$ & $3(3.3)$ & $3(2.5)$ & $2(66.7)$ & $5(18.5)$ \\
\hline R. felis & $31(31.0)$ & $4(44.4)$ & $16(17.5)$ & $51(25.3)$ & $2(2.8)$ & $2(14.3)$ & $0(0)$ & $4(4.3)$ & $1(4.2)$ & $2(66.7)$ & $4(14.8)$ \\
\hline R. bellii & $17(17.0)$ & $2(22.2)$ & $10(10.9)$ & $39(19.4)$ & $3(4.2)$ & $1(7.1)$ & $0(0)$ & $4(4.3)$ & $2(8.3)$ & $3(100)$ & $5(18.5)$ \\
\hline Ehrlichia canis & $3(3.0)$ & $0(0)$ & $1(1.1)$ & $4(2.0)$ & $33(46.5)$ & $4(28.6)$ & $1(14.3)$ & $38(41.3)$ & ND & ND & - \\
\hline Babesia canis vogeli & $0(0)$ & $0(0)$ & $0(0)$ & $0(0)$ & $25(46.5)$ & $6(42.9)$ & $0(0)$ & $31(33.7)$ & ND & ND & - \\
\hline Babesia bovis & $0(0)$ & $0(0)$ & $0(0)$ & $0(0)$ & ND & ND & ND & - & ND & ND & - \\
\hline Theileria equi & $0(0)$ & $0(0)$ & $0(0)$ & $0(0)$ & $0(0)$ & $0(0)$ & $0(0)$ & $0(0)$ & $24(100)$ & $3(100)$ & $27(100)$ \\
\hline \multicolumn{12}{|l|}{ PCR } \\
\hline Anaplasmataceae & $0(0)$ & $0(0)$ & $0(0)$ & $0(0)$ & $22(31.0)$ & $3(21.4)$ & $0(0)$ & $25(27.2)$ & $0(0)$ & $0(0)$ & $0(0)$ \\
\hline Borrelia & $0(0)$ & $0(0)$ & $0(0)$ & $0(0)$ & $0(0)$ & $0(0)$ & $0(0)$ & $0(0)$ & $0(0)$ & $0(0)$ & $0(0)$ \\
\hline Babesia/Theileria & $0(0)$ & $0(0)$ & $0(0)$ & $0(0)$ & $14(19.7)$ & $6(42.9)$ & $0(0)$ & $20(21.7)$ & $6(25.0)$ & $0(0)$ & $6(22.2)$ \\
\hline Hepatozoon* & ND & ND & ND & - & $46(64.8)$ & $8(57.1)$ & $0(0)$ & $54(58.7)$ & ND & ND & - \\
\hline
\end{tabular}

*Dados previamente relatados. ${ }^{45}$ 
Fig. 1. Localização dos seis municípios no Estado do Espírito Santo, Sudeste do Brasil, onde as amostras foram coletadas para o presente estudo.

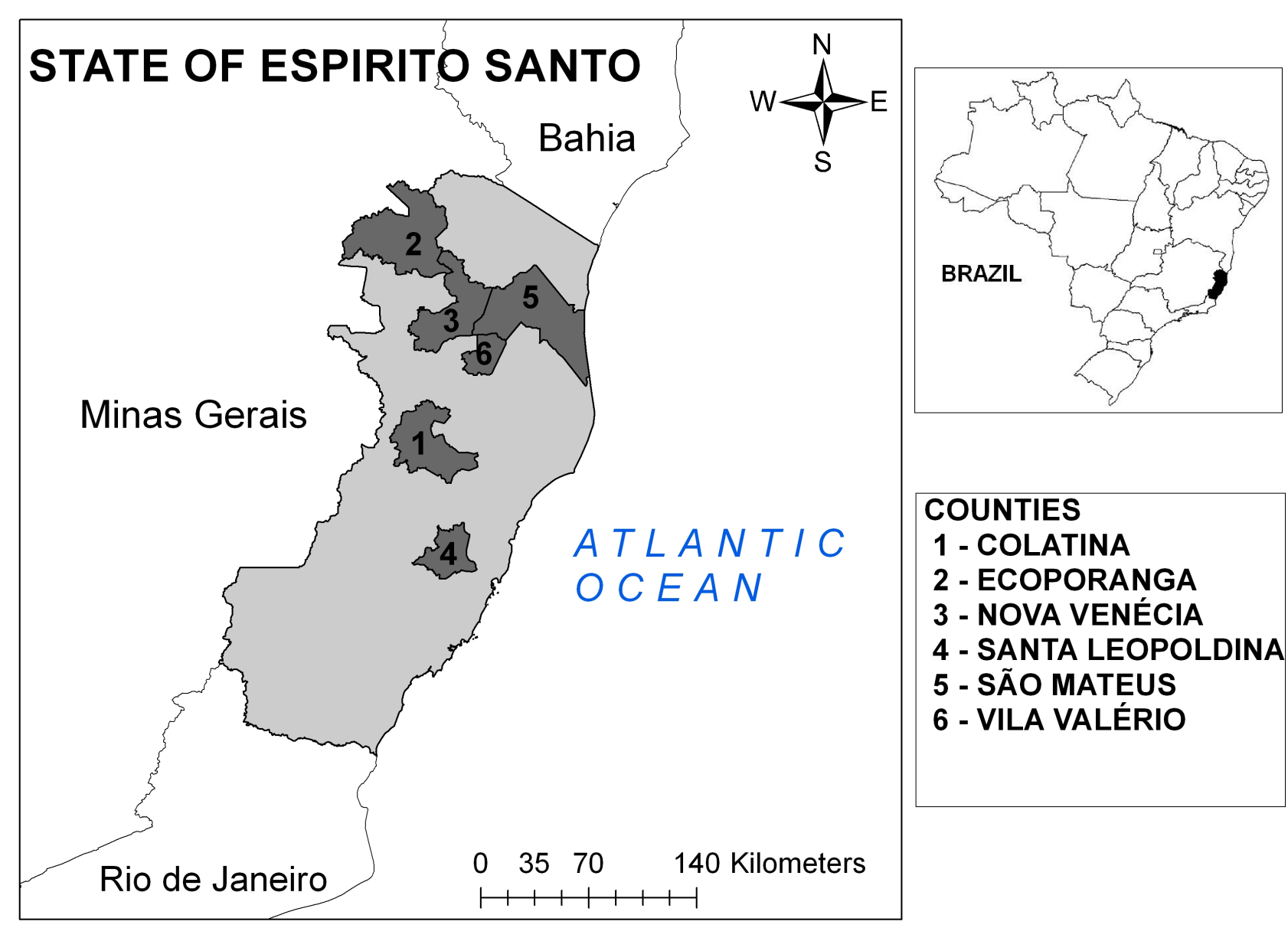


3. ARTIGO PUBLICADO NA Veterinary Parasitology, EM PORTUGUÊS 
Hepatozoon canis infectando cães no Estado do Espírito Santo, Sudeste do Brasil.

Mariana G. Spolidorio ${ }^{a,}{ }^{*}$, Marcelo B. Labruna ${ }^{b}$, Augusto M. Zago ${ }^{c}$, Dirlei M. Donatele $^{\mathrm{d}}$, Késia M. Caliari ${ }^{\mathrm{c}}$, Natalino H. Yoshinari ${ }^{\text {a }}$

a Laboratório de Investigação Médica 17 (LIM17), Faculdade de Medicina, Universidade de São Paulo, Av. Doutor Arnaldo 455, sala 3184, Cerqueira César, São Paulo, SP CEP 01246-903, Brazil

b Departamento de Medicina Veterinária Preventiva e Saúde Animal, Faculdade de Medicina Veterinária e Zootecnia, Universidade de São Paulo, Av. Prof. Orlando Marques de Paiva 87, Cidade Universitária, São Paulo, SP 05508-270, Brazil

c Núcleo de Vigilância em Saúde, Superintendência Regional de Saúde de Colatina, Rua Aroldo Antolini, s/n8, Prédio do INSS, 28 andar, Sala 214, Bairro Esplanada, Colatina, ES CEP 29702-080, Brazil

d Centro Universitário São Camilo Espírito Santo - CUSC, Rua São Camilo de Léllis, 01, Paraíso, Cachoeiro de Itapemirim, ES CEP 29304-910, Brazil

\section{RESUMO}

De maio de 2007 a março de 2008, amostras de sangue foram coletadas de 92 cães sadios vivendo em 21 residências (17 fazendas em áreas rurais, e 4 casas em área urbana) em 6 municípios do Estado do Espírito Santo, sudeste do Brasil. Adicionalmente, carrapatos foram coletados destes cães. Uma média de $4.4 \pm 3.0$ 
cães (variação 1-12) tiveram amostras coletadas por residência; 78 e 14 cães eram de áreas rurais e urbanas, respectivamente. Reação em Cadeia de Polimerase (PCR) projetados para amplificar fragmentos do gene 18S rDNA de Babesia spp ou Hepatozoon spp revelaram amplificados do tamanho esperado em 20 (21.7\%) cães para Babesia, e $54(58.7 \%)$ cães para Hepatozoon. Todos os cães positivos para Babesia foram também positivos para Hepatozoon. Entre as 21 residências, 15 (71.4\%) de 3 municípios apresentaram pelo menos um cão positivo na PCR, incluindo 13 fazendas (área rural) e 2 casas (área urbana). Um total de 40 produtos de PCR testados para Hepatozoon, e 19 produtos de PCR testados para Babesia foram submetidos ao sequenciamento de DNA. Todas as seqüências geradas das PCRs para Hepatozoon eram idênticas entre elas, e às sequiências correspondentes do gene $18 \mathrm{~S}$ rDNA de $H$. canis no GenBank. Cães de 10 residências rurais e 2 residências urbanas estavam infestados por carrapatos Rhipicephalus sanguineus. Estágios imaturos de carrapatos Amblyomma cajennense foram encontrados em cães de apenas 4 residências rurais (também infestados por $R$. sanguineus). Todas, exceto uma residência com cães infestados por $R$. sanguineus tiveram pelo menos um cão infectado por Hepatozoon. Analise estatística demonstrou que a presença de carrapatos (ex. R. sanguineus) infestando cães nas residências foi significativa $(P<$ 0.05) associada com pelo menos um cão positivo na PCR. Não houve associação significativa $(P>0.05)$ entre cães positivos na PCR e residências rurais ou urbanas. A Hepatozoonose canina causada por $H$. canis é uma infecção altamente freqüente no Espírito Santo, Brasil, onde ela é possivelmente transmitida por $R$. sanguineus. Visto que todos os cães infectados foram encontrados aparentemente sadios, a patogenicidade do $H$. canis em cães do Espírito Santo ainda está para ser elucidada. 


\section{INTRODUÇÃO}

A Hepatozoonose canina é uma doença transmitida por carrapatos de cães, encontrada praticamente em todo o mundo, causada por duas diferentes espécies de protozoários apicomplexos, Hepatozoon canis e Hepatozoon americanum (Baneth et al., 2003; Vincent-Johnson, 2003). H. canis foi descrito pela primeira vez na Índia em 1905, e foi incriminado como a causa de uma doença branda, principalmente caracterizada por anemia e letargia (Baneth e Weigler, 1997). Cães infectados por $H$. canis geralmente aparecem sadios, visto que a doença é geralmente não aparente e sub-clínica, e o diagnóstico é ocasionalmente confirmado durante exames laboratoriais (Mundim et al., 1994; Gondim et al., 1998; Paludo et al., 2005). A imunosupressão causada por doenças concomitantes ou outros fatores parecem ser fatores importantes na manifestação dos sinais clínicos. Em comparação, cães infectados por $H$. americanum tipicamente desenvolvem doença severa (VincentJohnson, 2003). A distribuição de $H$. americanum tem sido restrita aos Estados Unidos, enquanto que $H$. canis tem sido reportado na África, Sudeste da Ásia, Oriente Médio, Europa, e América do Sul (Baneth et al., 2003; Gavazza et al., 2003; Vincent-Johnson, 2003; Oyamada et al., 2005; Rubini et al., 2008).

No Brasil, a hepatozoonose canina foi descrita primeiramente por Massard (1979) em cães de uma área rural no Rio de Janeiro. Estudos moleculares recentes revelaram a espécie $H$. canis infectando cães dos Estados de São Paulo e Rio de Janeiro, e do Distrito Federal (Brasília) (Paludo et al., 2005; Forlano et al., 2007; Rubini et al., 2005, 2008). A avaliação clínica em cães infectados foi realizada em 
um destes estudos, o qual revelou doença branda similar à hepatozoonose canina previamente descrita no Velho Mundo (Paludo et al., 2005).

O vetor conhecido de $H$. canis no Velho Mundo é o carrapato Rhipicephalus sanguineus (Baneth et al., 2001), embora Haemaphysalis spp tenha sido sugerido como possíveis vetors no Japão (Murata et al., 1995). Nos Estados Unidos, Amblyomma americanum é o único carrapato reconhecido como vetor de $H$. americanum (Vincent-Johnson, 2003). No Brasil, Amblyomma spp foram sugeridos como vetores da hepatozoonose canina, embora $R$. sanguineus tenha sido também encontrado infestando cães infectados com H. canis (O’Dwyer et al., 2001; Forlano et al., 2005; Rubini et al., 2008).

O presente estudo empregou análise molecular para avaliar a infecção por Hepatozoon spp e Babesia spp em cães do Estado do Espírito Santo, Sudeste do Brasil. Adicionalmente, nós avaliamos as espécies de carrapatos que estavam infestando estes cães.

\section{MATERIAIS E MÉTODOS}

Durante maio de 2007 e março de 2008, três expedições científicas foram realizadas para o Estado do Espírito Santo, região Sudeste do Brasil. Em cada expedição, fazendas em áreas rurais e residências em localidades urbanas foram visitadas em seis municípios: Nova Venécia (188430S, 408240W), São Mateus (188430S, 398510W), Santa Leopoldina (208060S, 408320W), Ecoporanga (188220S, 408500W), Colatina (198320S, 408370W), e Vila Valério (188590S, 408220W). Um total de 92 cães aparentemente sadios foram amostrados de 21 
localidades (17 fazendas e 4 residências). Estas residências foram previamente selecionadas para outro estudo com doenças transmitidas por carrapatos (N.H.Y., dado não publicado), portanto não foram selecionadas aleatoriamente.

Amostras de sangue dos cães foram coletadas em tubos com anticoagulante ácido ethylenediaminetetraacetico (EDTA), e mantidos congeladosa $-20^{\circ} \mathrm{C}$ até a extração de DNA. DNA foi extraído de cada amostra de sangue utilizando-se o kit DNeasy Blood \& Tissue (Qiagen, Hilden, Alemanha), de acordo com as instruções do fabricante. As amostras de DNA foram eluídas em $100 \mu \mathrm{L}$ de solução de TE. Cinco microlitros do DNA extraído foram utilizados na amplificação pela Reação em Cadeira de Polimerase (PCR). Água livre de DNA foi utilizada como controle negativo para as extrações e para os ensaios de PCR.

Os primers HEP-1 mod (50-CGC GAA ATT ACC CAA TTC TA -30) e HEP-4 (50-TAA GGT GCT GAA GGA GTC GTT TAT-30), foram utilizados para amplificar uma porção de $\approx 670$-pb do gene $18 \mathrm{~S}$ rRNA de Hepatozoon spp (CriadoFornelio et al., 2006). O primer HEP-1 mod foi modificado do primer HEP-1 relatado por Criado-Fornelio et al. (2006) através da inserção dos três últimos nucleotídeos (CTA), que são conservados entre sequências de Hepatozoon disponíveis no GenBank. Esta inserção foi feita com a intenção de aumentar a temperatura de anelamento do primer. Adicionalmente, primers BAB-33-57 (50GCC AGT AGT CAT ATG CTT GTC TTAA-30) e BAB-432-409 (50-TTC CTT AGA TGT GGT AGC CGT TTC-30), correspondentes a regiões conservadas do gene 18S rRNA de Babesia spp foram desenhados para amplificar uma porção de ₹370-pb do gene 18S rRNA. Reações em Cadeia de Polimerase (PCR) foram realizadas em um total de $50 \mu \mathrm{L}$ de solução contendo $1 \mathrm{X}$ PCR buffer sem $\mathrm{Mg}, 1.5$ 
$\mathrm{mM} \mathrm{MgCl2}, 0.2 \mathrm{mMdNTPs}, 1 \mathrm{U}$ of Platinum TaqDNA Polymerase (Invitrogen, Carlsbad, CA), e $0.2 \mathrm{mM}$ de cada primer. As condições dos ciclos de temperatura da PCR para Hepatozoon spp consistiu em uma desnaturação inicial por 3 min a $95^{\circ} \mathrm{C}$, e 40 ciclos repetitivos de $15 \mathrm{~s}$ a $95^{\circ} \mathrm{C}, 40 \mathrm{~s}$ a $53^{\circ} \mathrm{C}$. e $4-\mathrm{s}$ a $72^{\circ} \mathrm{C}$, seguidos por uma extensão final de 5 min a $72^{\circ} \mathrm{C}$. As condições dos ciclos de temperatura para os primers de Babesia spp consistiu em uma desnaturação inicial de 3 min a $95^{\circ} \mathrm{C}$, e 35 ciclos repetitivos de $15 \mathrm{~s}$ a $95^{\circ} \mathrm{C}, 30 \mathrm{~s}$ a $63^{\circ} \mathrm{C}$, e $30 \mathrm{~s}$ a $72^{\circ} \mathrm{C}$, seguidos por uma extensão final de 7 min a $72^{\circ} \mathrm{C}$. Ambos os ciclos foram previamente submetidos a um gradiente de temperatura para encontrar a melhor temperatura de anelamento para as nossas condições laboratoriais. Os produtos de PCR foram submetidos a eletroforese em gel de agarose 1.5\%, corados com Brometo de Etídeo, e examinados através de transiluminador UV. "Amplicons" do tamanho esperado foram purificados com ExoSap (USB) e sequenciados em seqüenciador automático (Applied Biosystems/PerkinElmer, model ABI Prism 310 Genetic, Foster City, CA) de acordo com o protocolo do fabricante.As sequências parciais obtidas foram submetidas a análise BLAST (Altschul et al., 1990) para determinar as similaridades mais próximas das sequências correspondentes.

Durante as coletas de sangue, os cães foram examinados para a presença de carrapatos, os quais foram coletados e trazidos ao laboratório para identificação taxonômica. Para análise estatística, a presença de ao menos um cão positivo na PCR em cada fazenda ou casa foi analisada qualitativamente em nível dicotômico ( 0 : fazenda ou casa sem cães positivos na PCR; 1: fazenda ou casa com ao menos um cão positivo na PCR) com as seguintes variáveis independentes por análise univariante (Teste exato de Fisher): (i) presença de carrapatos infestando cães na 
fazenda ou casa (0: ausente; 1 : presente); e (ii) local de moradia (0: área urbana; 1 : área rural). Associação estatística entre variáveis foi considerada significante se $P<$ 0.05. Todas as análises foram realizadas utilizando o programa EpiInfo (versão 3.3.2).

Tabela 1. Resultados da PCR para amplificar uma porção do gene 18S rDNA de Hepatozoon spp em amostras de sangue de cães de localidades em seis municípios no Estado do Espírito Santo, Brasil.

\begin{tabular}{lcc}
\hline Município & $\begin{array}{c}\text { No. de localidades com ao menos um } \\
\text { cão positivo na PCR / No. total de } \\
\text { localidades }(\%)\end{array}$ & $\begin{array}{c}\text { No. de cães positivos na } \\
\text { PCR / No. total de cães }\end{array}$ \\
& $0 / 1(0)$ & $0 / 8(0)$ \\
\hline Colatina & $1 / 1(100)$ & $2 / 3(66.6)$ \\
Ecoporanga & $10 / 13(77.0)$ & $40 / 54(74.1)$ \\
Nova Venécia & $0 / 1(0)$ & $0 / 12(0)$ \\
Santa Leopoldina & $4 / 4(100)$ & $0 / 2(0)$ \\
São Mateus & $0 / 1(0)$ & 54 / $92(58.7)$ \\
Vila Valério & $15 / 21(71.4)$ & \\
Total & & $12.3)$ \\
\hline
\end{tabular}

\section{RESULTADOS}

Uma média de $4.4 \pm 3.0$ cães (variação: 1-12) foram amostrados por localidade, totalizando 92 cães sadios; 78 cães eram de fazendas em áreas rurais, e 14 cães eram de residências em áreas urbanas. Um total de 20 (21.7\%) cães foram positivos no protocolo de PCR para Babesia, enquanto 54 (58.7\%) foram positivos 
no protocolo de PCR para Hepatozoon. Todos os cães positivos para Babesia foram também positivos para Hepatozoon. Entre as 21 localidades, $15(71.4 \%)$ em 3 municípios tiveram ao menos um cão positivo na PCR (Tabela 1); isto incluiu 13 fazendas (área rural) e 2 residências (área urbana).

Um total de 40 produtos de PCR provenientes da PCR para Hepatozoon, e 19 produtos provenientes da PCR para Babesia foram submetidos ao seqüenciamento de DNA. Foi tomado o devido cuidado para que fossem seqüenciados produtos de ao menos 2 cães diferentes de todas as localidades que tiveram 2 ou mais amostras positivas na PCR. Todas as sequências geradas da PCR para Hepatozoon foram idênticas entre si, e às sequências correspondentes do gene $18 \mathrm{~S}$ rRNA de $H$. canis no GenBank. Surpreendentemente, todas as sequências geradas da PCR para Babesia eram idênticas às sequências correspondentes ao gene $18 \mathrm{~S}$ rRNA de $H$. canis no GenBank. Após a análise BLAST, estas sequências demonstraram 100\% de homologia à $H$. canis detectado em raposas da Espanha e Eslováquia, e também em dois Estados do Brasil: Rio Grande do Sul (em Cerdocyon thous e Pseudalopex gymnocercus) e Brasília (cães domésticos). Os números de acesso no GenBank destes isolados previamente descritos são AY150067, AY461375, AY471615, AY864677, DQ869309, respectively (Criado-Fornelio et al., 2006; Paludo et al., 2005; Majla'thova' et al., 2007).

Cães de 10 localidades rurais e 2 localidades urbanas foram encontrados infestados por carrapatos $R$. sanguineus. Estágios imaturos de carrapatos Amblyomma sp foram encontrados em cães de apenas 4 localidades (infestados também por $R$. sanguineus). Amostras destes estágios imaturos foram cultivados no laboratório até o estágio adulto, e foram identificados como Amblyomma cajennense. 
Todas, exceto uma residência com cães infestados por $R$. sanguineus teve ao menos um cão infectado por Hepatozoon. Pela análise univariante, a presença de carrapatos (ex. R. sanguineus) infestando cães na localidade foi significante $(P<0.05)$ associada com ao menos um cão positivo na PCR. Não houve associação significativa $(P>0.05)$ entre cães positivos na PCR e localidades urbanas ou rurais.

\section{DISCUSSÃO}

O presente estudo demonstrou que a infecção em cães por $H$. canis foi comum entre os cães aparentemente sadios no Estado do Espírito Santo, com uma média absoluta de infecção de $58.7 \%$. Este valor está dentro das médias de infecção previamente reportadas entre cães rurais sadios de outras partes do Brasil, que variaram entre 39.2 a $67.7 \%$ nos Estados de São Paulo e Rio de Janeiro (O’Dwyer et al., 2001; Rubini et al., 2005, 2008).

Embora nós tentemos encontrar DNA de Babesia através da PCR empregando primers supostamente específicos para este gênero de protozoários, o sequenciamento de DNA de todos os "amplicons" gerados do tamanho esperado por estes primers apareceram como H. canis. Está amplificação “inesperada” ocorreu no presente estudo porque nossos primers para Babesia têm um alto grau de homologia com as sequências correspondentes ao gene 18S rRNA de Hepatozoon canis (Tabela 2), ex. nossos primers não são específicos para o gênero Babesia. Infelizmente, nós não fizemos esta análise de alinhamento antes de trabalhar com estes primers para Babesia neste estudo, procedimento que teria nos levado a utilizar outros primers com maior especificidade para Babesia spp. Semelhantes faltas de especificidade 
com primers desenhados para Babesia foram previamente relatados em outros estudos, onde sequências "inesperadas" de Hepatozoon também foram geradas (Oyamada et al., 2005; Majláthová et al., 2007). Provavelmente, estes autores também trabalharam com primers que demonstraram alto grau de homologia com sequências correspondentes à Hepatozoon canis. Baseado nestes resultados, não é possível descartar a possibilidade da infecção canina por Babesia sp nas amostras de cães testados no presente estudo, especialmente se a infecção estava com baixas taxas, porque um cão com uma possível infecção dupla por $H$. canis e Babesia sp poderia gerar somente sequências de $H$. canis nas nossas análises.

Tabela 2. Alinhamento de sequências de nucleotídeos para a região do gene $18 \mathrm{~S}$ rRNA de Apicomplexos Babesia spp e Hepatozoon canis, correspondentes aos primers BAB-33-57 e BAB432-409.

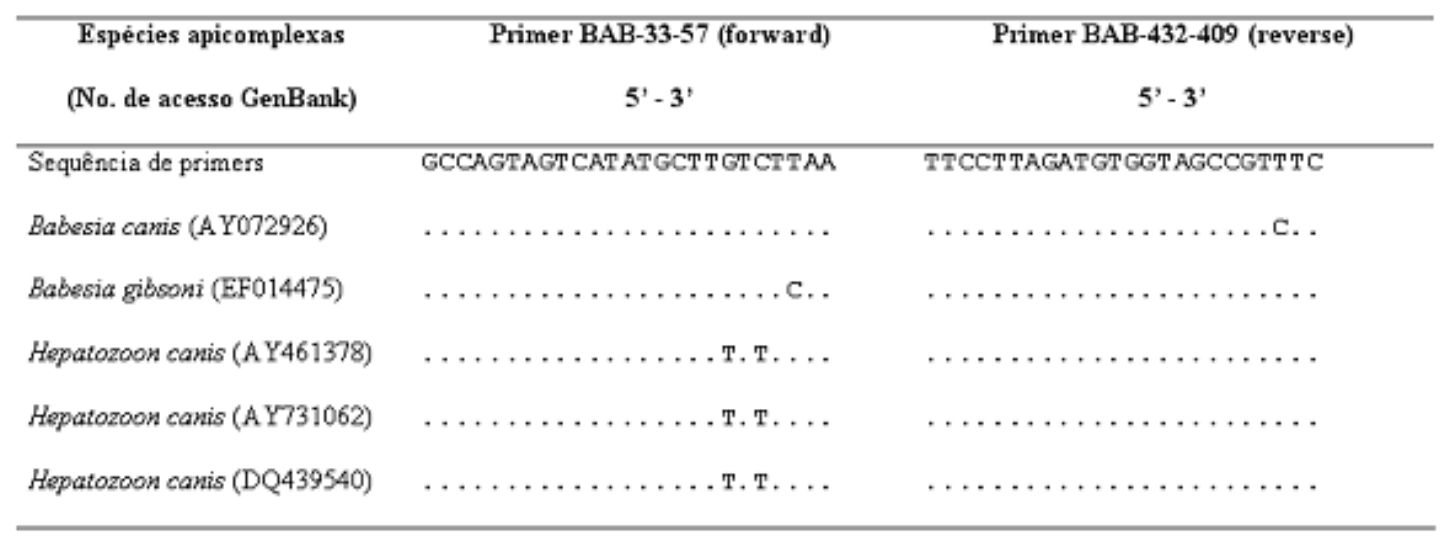

Os resultados do presente estudo indicam o $R$. sanguineus como o possível vetor de $H$. canis no Estado do Espírito Santo. Cães no Brasil são geralmente encontrados infestados por $R$. sanguineus em áreas urbanas, e por ambos Amblyomma spp e $R$. sanguineus em áreas rurais (O’Dwyer et al., 2001; Szabó et al., 2001; Rubini et al., 2008). A maioria dos cães amostrados neste estudo era de áreas 
rurais, onde encontramos uma alta porcentagem de infecção por $H$. canis em uma significante associação com a infestação por $R$. sanguineus. Não foram encontradas diferenças entre as proporções de localidades com cães infectados por $H$. canis entre áreas urbanas e rurais. Esta falta de uma diferença significativa pode ser relacionada à ocorrência frequente de $R$. sanguineus em ambas áreas urbanas e rurais, mas também pode estar relacionada ao pequeno número de residências urbanas analisadas no presente estudo. A confirmação do vetor da hepatozoonose canina no Brasil tem sido uma questão controversa. Um estudo no Estado do Rio de Janeiro encontrou uma associação significativa entre a infestação por A. cajennense e a presença de gamontes de H. canis em esfregaços de sangue de cães (O'Dwyer et al., 2001). Adicionalmente, Amblyomma aureolatum foi a única espécie de carrapato encontrada infestando raposas infectadas por $H$. canis no Sul do Brasil (Criado-Fornelio et al., 2006). Outro estudo confirmou o Amblyomma ovale como sendo o possível vetor de H. canis no Rio de Janeiro, como demonstrado por transmissão experimental e o encontro de um carrapato naturalmente infectado (Forlano et al., 2005, 2007). Por outro lado, vários estudos no Brasil encontraram cães infectados sendo infestados por ambos carrapatos Amblyomma spp e $R$. sanguineus (O'Dwyer et al, 2001; Rubini et al., 2008). R. sanguineus tem sido considerado o principal vetor de $H$. canis no Velho Mundo, onde a transmissão experimental deste protozoário por $R$. sanguineus foi elegantemente demonstrada (Baneth et al., 2001). Possivelmente, ambos $R$. sanguineus e algumas espécies de Amblyomma têm seu papel na transmissão de $H$. canis no Brasil. 


\section{CONCLUSÃO}

A hepatozoonose canina causada por $H$. canis parece ser uma infecção de ocorrência frequente em áreas onde $R$. sanguineus é endêmico. Visto que todos os cães infectados foram encontrados aparentemente sadios, a patogenicidade de $H$. canis em cães no Espírito Santo permanece desconhecida.

\section{AGRADECIMENTOS}

Somos gratos a Denise M. Mancini [Coordenação Geral de Laboratórios de Saúde Pública (CGLAB), Secretaria de Vigilância em Saúde (SVS) do Ministério da Saúde (MS)], e Regina M. B. Terrão (Lacen Espírito Santo) pelo apoio logístico no Espírito Santo, e aos Agentes Locais de Vigilância Ambiental em Saúde do Departamento de Vigilância Ambiental do Município de Nova Venécia, ES, pela ajuda valiosa durante os trabalhos de campo. Este estudo contou com o apoio financeiro da Fundação de Amparo à Pesquisa do Estado de São Paulo (concessão FAPESP 07/51899-2 para N.H.Y.), Coordenação de Aperfeiçoamento de Pessoal de Nível Superior (bolsa de doutorado direto CAPES para M.G.S.) e Conselho Nacional de Desenvolvimento Científico e Tecnológico (bolsa de produtividade em pesquisa CNPq para M.B.L.). 


\section{REFERÊNCIAS BIBLIOGRÁFICAS}

Altschul, S.F., Gish, W., Miller, W., Myers, E.W., Lipman, D.J., 1990. Basic local alignment search tool. J. Mol. Biol. 215, 403-410.

Baneth, G., Weigler, B., 1997. Retrospective case-control study of hepatozoonosis in dogs in Israel. J. Vet. Intern. Med. 11(6), 365-70.

Baneth, G., Samish, M., Alekseev, E., Aroch, I., Shkap, V., 2001. Transmission of Hepatozoon canis to dogs by naturally-fed or percutaneously-injected Rhipicephalus sanguineus ticks. J. Parasitol. 87(3), 606-11.

Baneth, G., Mathew, J.S., Shkap, V., Macintire, D.K., Barta, J.R., Ewing, S.A., 2003. Canine hepatozoonosis: two disease syndromes caused by separate Hepatozoon spp. Trends. Parasitol. 19(1), 27-31.

Criado-Fornelio, A., Ruas, J.L., Casado, N., Farias, N.A., Soares, M.P., Müller, G., Brumt, J.G., Berne, M.E., Buling-Saraña, A., Barba-Carretero, J.C., 2006. New molecular data on mammalian Hepatozoon species (Apicomplexa: Adeleorina) from Brazil and Spain. J. Parasitol. 92(1), 93-9.

Forlano, M., Scofield, A., Elisei, C., Fernandes, K.R., Ewing, S.A., Massard, C.L., 2005. Diagnosis of Hepatozoon spp. in Amblyomma ovale and its experimental transmission in domestic dogs in Brazil. Vet. Parasitol. 134(1-2), 1-7.

Forlano, M.D., Teixeira, K.R., Scofield, A., Elisei, C., Yotoko, K.S., Fernandes, K.R., Linhares, G.F., Ewing, S.A., Massard, C.L., 2007. Molecular characterization of Hepatozoon sp. from Brazilian dogs and its phylogenetic relationship with other Hepatozoon spp. Vet. Parasitol. 145(1-2), 21-30. 
Gavazza, A., Bizzeti, M., Papini, R., 2003. Observations on dogs found naturally infected with Hepatozoon canis in Italy. Rev. Med. Vet. 154 (8-9), 565-571.

Gondim, F.P., Kohayagawa, A., Alencar, N.X., Biondo, A.W., Takahira, R.K., Franco, S.R.V., 1998. Canine hepatozoonosis in Brazil: description of eight naturally occurring cases. Vet. Parasitol. 74(2-4), 319-23.

Majláthová, V., Hurníková, Z., Majláth, I., Petko, B., 2007. Hepatozoon canis infection in Slovakia: imported or autochthonous? Vector Borne Zoonotic Dis. $7(2), 199-202$.

Massard, C.A., 1979. Hepatozoon canis (James, 1905) (Adeleida : Hepatozoidae) em cães do Brasil, com uma revisão do gênero em membros da ordem carnívora. Seropédica, Tese (Mestrado em Medicina Veterinária - Parasitologia Veterinária). Departamento de Parasitologia, Universidade Federal Rural do Rio de Janeiro, $121 \mathrm{pp}$.

Mundim, A.V., Mundim, M.J.S., Jensen, N.M.P., Araujo, S.F., 1994. Hepatozoon canis: estudo retrospectivo de 22 casos de infecção natural em cães de Uberlândia, MG. Ver. Cent. Ci. Biom. Univ. Fed. de Uberlândia 10(1), 89-95.

Murata, T., Inoue, M., Taura, Y., 1995. Detection of Hepatozoon canis oocysts from ticks collected from infected dogs. J. Vet. Med. Sci. 75, 111-112.

O'Dwyer, L.H., Massard, C.L., Pereira de Souza, J.C., 2001. Hepatozoon canis infection associated with dog ticks of rural areas of Rio de Janeiro State, Brazil. Vet. Parasitol. 94(3), 143-50.

Oyamada, M., Davoust, B., Boni, M., Dereure, J., Bucheton, B., Hammad, A., Itamoto, K., Okuda, M., Inokuma, H., 2005. Detection of Babesia canis rossi, B. canis vogeli, and Hepatozoon canis in dogs in a village of eastern Sudan by using 
a screening PCR and sequencing methodologies. Clin. Diagn. Lab. Immunol. 12(11), 1343-6.

Paludo, G.R., Friedmann, H., Dell'Porto, A., Macintire, D.K., Whitley, E.M., Boudreaux, M.K., Baneth, G., Blagburn, B.L., Dykstra, C.C., 2005. Hepatozoon spp.: pathological and partial 18S rRNA sequence analysis from three Brazilian dogs. Parasitol. Res. 97(2), 167-70.

Rubini, A.S., dos Santos Paduan, K., Cavalcante, G.G., Ribolla, P.E., O'Dwyer, L.H., 2005. Molecular identification and characterization of canine Hepatozoon species from Brazil. Parasitol. Res. 97(2), 91-3.

Rubini, A.S., dos Santos Paduan, K., Von Ah Lopes, V., O'Dwyer, L.H., 2008. Molecular and parasitological survey of Hepatozoon canis (Apicomplexa: Hepatozoidae) in dogs from rural area of Sao Paulo state, Brazil. Parasitol. Res. 102(5), 895-9.

Szabó, M.P., Cunha, T.M., Pinter, A., Vicentini, F., 2001. Ticks (Acari: Ixodidae) associated with domestic dogs in Franca region, São Paulo, Brazil. Exp. Appl. Acarol. 25(10-11), 909-16.

Vincent-Johnson, N.A., 2003. American canine hepatozoonosis. Vet. Clin. North. Am. Small. Anim. Pract. 33(4), 905-20. 
Foi possível traçar um perfil epidemiológico das áreas estudadas na região Norte do Estado do Espírito Santo, levando-se em consideração que estudamos uma população de pessoas aparentemente sadias, sem quadros clínicos de zoonoses transmitidas por carrapatos (ZTCs), mas que estão em contato frequente com estes artrópodes, vivendo em área rural e convivendo com animais domésticos que estão infectados por diversos agentes transmitidos por carrapatos.

Este projeto de pesquisa contou com o apoio logístico do Ministério da Saúde, o qual tornou possíveis as visitas técnicas para coleta de materiais na região. Acreditamos que a importância deste projeto como um primeiro modelo é apenas um passo inicial em âmbito nacional no estudo de ZTCs, e várias outras localidades no Brasil sob as mesmas condições de saneamento e epidemiologia poderiam ser estudadas e pesquisadas para as ZTCs.

É possível concluir que os municípios do Estado do Espírito Santo estudados nesta pesquisa por agentes transmitidos por carrapatos podem ser considerados áreas endêmicas para as Riquetsioses de modo geral. Em se tratando dos animais, a problemática é maior, pois estes estão muito mais expostos ao contato com carrapatos e às bactérias e protozoários por estes transmitidos. As principais doenças em cães da região são a Erliquiose, Hepatozoonose canina, Babesiose e as Riquetsioses, sendo que no caso das riquetsioses não podemos afirmar quais espécies de Rickettsia estão realmente circulantes na região, apenas podemos inferir que existe a possibilidade destes animais terem tido contato prévio com $R$. felis, talvez através de pulgas (Ctenocephalides felis felis) infectadas por esta Rickettsia . Os cães estudados estavam geralmente parasitados pelas mesmas espécies de carrapatos que infestam os humanos, e assim os cães podem ser considerados bons sentinelas para a 
presença de Riquétsias e Febre Maculosa Brasileira. Os equinos também são importantes sentinelas no estudo da FMB, pois são hospedeiros de estágios imaturos e adultos de carrapatos Amblyomma cajennense.

Com relação à SBY, os resultados sorológicos para B. burgdorferi, principalmente em cães, sugerem que o agente etiológico causador desta síndrome possa estar circulante, e possa se tratar de uma espiroqueta modificada morfologicamente e/ou geneticamente, motivo pelo qual os ensaios de PCR para Borrelia não são eficientes para identificar este organismo.

A divulgação dos resultados encontrados é de suma importância para toda a comunidade médica e veterinária do Brasil e do mundo, acrescentando dados novos e abrindo o leque de tópicos a serem pesquisados e desenvolvidos no futuro, aprimorando metodologias, formando novos laços entre pesquisadores e formando recursos humanos qualificados para a pesquisa brasileira. 
ANEXO 1

American Journal of Tropical Medicine \& Hygiene

The American Journal of

Tropical Medicine and Hygiene

Survey for tick-borne zoonoses in the State of Espirito Santo, southeastern Brazil

\begin{tabular}{|c|c|}
\hline Journal: & American Journal of Tropical Medicine \& Hygiene \\
\hline Manuscript ID: & Draft \\
\hline Manuscript Type: & Original Research Paper \\
\hline \multicolumn{2}{|l|}{$\begin{array}{r}\text { Date Submitted by the } \\
\text { Author: }\end{array}$} \\
\hline Complete List of Authors: & $\begin{array}{l}\text { Spolidorio, Mariana; Faculty of Medicine, University of São Paulo, } \\
\text { Rheumatology } \\
\text { Labruna, Marcelo; University of Sao Paulo, Preventive Veterinary } \\
\text { Medicine } \\
\text { Machado, Rosangela; UNESP-FCAV, Veterinary Pathology } \\
\text { Moraes-Filho, Jonas; University of Sao Paulo, Preventive Veterinary } \\
\text { Medicine } \\
\text { Zago, Augusto; Nucleo de Vigilancia em Saude, Superintendencia } \\
\text { Regional de Saude de Colatina } \\
\text { Donatele, Dirlei; Centro Universitario Sao Camilo Espirito Santo, } \\
\text { Parasitologia } \\
\text { Silveira, Iara; University of Sao Paulo, Preventive Veterinary } \\
\text { Medicine } \\
\text { Caliari, Kesia; Nucleo de Vigilancia em Saude, Superintendencia } \\
\text { Regional de Saude de Colatina } \\
\text { Yoshinari, Natalino; Faculty of Medicine, University of Sao Paulo, } \\
\text { Rheumatology }\end{array}$ \\
\hline Key Words: & $\begin{array}{l}\text { Babesiosis, Ehrlichiosis, Epidemiology, Parasitology, Rickettsial } \\
\text { Diseases, Ticks, Zoonotic Diseases, Vector-borne diseases }\end{array}$ \\
\hline
\end{tabular}

\$) ScholaroNE" 
Survey for tick-borne zoonoses in the State of Espirito Santo, southeastern Brazil

Mariana G. Spolidorio, Marcelo B. Labruna, Rosangela Z. Machado, Jonas Moraes-Filho, Augusto M. Zago, Dirlei M. Donatele, Iara Silveira, Késia M. Caliari, and Natalino H. Yoshinari

Laboratório de Investigação Médica 17 (LIM17), Faculdade de Medicina, Universidade de São Paulo, São Paulo, Brazil; Departamento de Medicina Veterinária Preventiva e Saúde Animal, Faculdade de Medicina Veterinária e Zootecnia, Universidade de São Paulo, São Paulo, Brazil; Departamento de Patologia Veterinária, Faculdade de Ciências Agrárias e Veterinárias, Universidade Estadual Paulista “Julio de Mesquita Filho”, Jaboticabal, Brazil; Núcleo de Vigilância em Saúde, Superintendência Regional de Saúde de Colatina, Colatina, Espírito Santo, Brazil;Centro Universitário São Camilo Espírito Santo, Cachoeiro de Itapemirim, Espírito Santo, Brazil. 


\title{
Survey for tick-borne zoonoses in the State of Espirito Santo, southeastern Brazil
}

\begin{abstract}
Blood samples collected from 201 humans, 92 dogs, and 27 horses in the state of Espirito Santo, Brazil, were tested by polymerase chain reaction (PCR), indirect immunofluorescence assays (IFA), and indirect ELISA for tick-borne diseases (rickettsiosis, ehrlichiosis, anaplasmosis, borreliosis, babesiosis). Our results indicated that the surveyed counties are endemic for spotted fever group rickettsiosis because sera from $70(34.8 \%)$ humans, 7 (7.6\%) dogs, and 7 (25.9\%) horses were reactive to at least one of the six Rickettsia species tested. While there was evidence of ehrlichiosis (Ehrlichia canis) and babesiosis (Babesia canis vogeli, Theileria equi) in domestic animals, no human was positive for babesiosis and only 4 individuals were serologically positive for E. canis. Borrelia burgdorferi-serologic reactive sera were rare among humans and horses, but encompassed $51 \%$ of the canine samples, suggesting that dogs and their ticks can be part of the epidemiological cycle of the causative agent of the Brazilian zoonosis, named Baggio-Yoshinari Syndrome.
\end{abstract}

\section{INTRODUCTION}

Brazilian spotted fever (BSF), a rickettsial disease caused by Rickettsia rickettsii, is the most prevalent tick-borne zoonosis in Brazil, where its first reports dated from the 1930s. ${ }^{1,2}$ The Brazilian southeastern states (São Paulo, Minas Gerais, Rio de Janeiro and Espírito Santo) are considered endemic for BSF, however most of the studies have been conducted in the first three states, with only two reported studies in the state of Espirito Santo. ${ }^{3-8}$ 
Lyme Disease-like syndrome is an emerging clinical entity that has been described in Brazil, and imitates the clinical manifestations of the classical Lyme Disease from the northern hemisphere. However, no spirochetes have been identified in Brazilian patients and ticks, despite of exhaustive use of molecular and microbiological assays on clinical samples. ${ }^{9}$ The nomenclature of the Brazilian disease was renamed to Baggio-Yoshinari Syndrome (BYS) during the Rheumatology meeting in São Paulo, 2005, proposing a new tick-borne zoonosis in the country, different from Lyme Disease, probably caused by different species of spirochetes or a modified one (N.H.Y., unpublished data).

Canine monocytic ehrlichiosis, caused by Ehrlichia canis, is the most important tickborne disease of dogs in Brazil. E. canis is currently the only ehrlichial species that has been isolated from vertebrates in South America. ${ }^{10-12}$ A preliminary investigation of Ehrlichia species was developed in the north and southeastern regions of Brazil, including various tick species, humans, dogs, and capybaras, but no Ehrlichia DNA was found in human samples. ${ }^{13}$ In contrast, ehrlichial DNA compatible with Ehrlichia chaffeensis and Ehrlichia ewingii was recently reported in animal blood samples in Brazil. ${ }^{14,15}$ Human cases of ehrlichiosis in Brazil were only reported by clinical suspects and serological tests, with no DNA amplification and further identification of the agent. ${ }^{16,17}$

Babesiosis is a common tick-borne disease of dogs and horses in Brazil. Babesia canis vogeli $(=B$. vogeli $)$ is the most common agent affecting dogs, although there are a few reports of Babesia gibsoni. ${ }^{18-21}$ Babesiosis in equids are caused mainly by Babesia caballi and Theileria equi (formerly Babesia equi), which are endemic at the tropics, subtropics and partly in the temperate zones. ${ }^{22}$ In the North Hemisphere, human babesiosis is found in the United States, where three different species are known to occur, and also in Europe, where the main species identified in humans are B. divergens, B. microti and B. odocolei. ${ }^{23-25}$ South America has a low number of reports of human babesiosis, including the first suspect case 
from the State of Pernambuco, a serological study in Colombia, a possible positive case in Poland that seems to have acquired in Brazil, antibodies to Babesia in a study of co-infection with Lyme disease, and a case of a child with hepatoblastoma with a positive blood smear that suggests Babesia infection. ${ }^{26-30}$

With the aim to investigate tick-borne zoonoses and to establish epidemiological data about these diseases in the northern region of the State of Espírito Santo, we visited six counties in this area, and performed serology and molecular biology to the most common tick-borne diseases in humans and domestic animals in Brazil. These counties were selected because of their recent history of BSF laboratory-confirmed cases, including fatal cases (unpublished data from the State of Espírito Santo Health Secretary), and/or suspect cases of BYS (N.H.Y., unpublished data).

\section{MATERIAL AND METHODS}

This study sampled humans, dogs, and horses living in 23 localities in the rural and urban areas within 6 municipalities located in the State of Espírito Santo, Brazil: Nova Venécia, São Mateus, Santa Leopoldina, Ecoporanga, Colatina, and Vila Valério (Figure 1). Samples were collected from May 2007 to March 2008 during three scientific expeditions undertaken to the State of Espírito Santo. In each expedition, farms in rural and homes in urban localities were visited in order to collect blood samples from humans, dogs, and horses. None of the sampled individuals presented clinical signs of acute infectious diseases when the blood was collected. A total of 109 humans, 85 dogs, and 24 horses were sampled from 22 households (17 farms and 5 homes). In addition, 92 humans, 7 dogs, and 3 horses were sampled in an Agro-Technical school located in the rural area of Colatina County. Collection of animal and human blood samples were previously approved by Ethical Principles of Ethics 
Commission to research projects (CAPPesq), Faculty of Medicine, University of São Paulo. Four of the rural households were considered to be the infection source of BSF cases (presumably caused by $R$. rickettsii) confirmed in humans during 2003-2005 with at least 4 fatalities (unpublished data from the State of Espírito Santo Health Secretary). The remaining 18 households were considered the probable infection source of Lyme Disease-like syndrome [= Baggio-Yoshinari syndrome (BYS)] among human patients (Yoshinari NH, unpublished data), and were selected because of a large number of B. burgdorferi-serologically positive samples sent to the BYS Reference Laboratory at the Faculty of Medicine of the University of São Paulo. Blood samples were collected in two vials: one with ethylenediaminetetraacetic acid (EDTA) anticoagulant, and kept frozen at $-20^{\circ} \mathrm{C}$ until DNA extraction; and the other without EDTA, from which sera were separated by centrifugation and kept frozen until tested by serological methods.

DNA extraction and polymerase chain reaction (PCR). DNA was extracted from each blood sample using the DNeasy Blood \& Tissue Kit (Qiagen, Hilden, Germany), according to the manufacturer's instructions. DNA samples were eluted in $100 \mathrm{~mL}$ of TE buffer. Free DNA water was used as negative control of the extractions. Five-microliters of extracted DNA were used for polymerase chain reaction (PCR) amplification. Samples were individually tested by a battery of PCR using the protocols described below.

Primers GE2 (5 - GTT AGT GGC AGA CGG GTG AGT - 3`) e HE3 (5`- TAT AGG TAC CGT CAT TAT CTT CCC TAT - 3`) were used to amplify a 360 bp fragment of the 16S rRNA gene of Anaplasmataceae. ${ }^{31-33}$ PCR were carried out in a total of $50 \mu \mathrm{L}$ solution containing 1X PCR buffer minus $\mathrm{Mg}, 1.5 \mathrm{mM} \mathrm{MgCl}_{2}, 0.2 \mathrm{mM}$ dNTPs, $1 \mathrm{U}$ of Platinum TaqDNA Polymerase (Invitrogen, Carlsbad, CA), and $0.2 \mu \mathrm{M}$ of each primer. PCR cycle conditions consisted of a initial denaturation for $5 \mathrm{~min}$ at $95^{\circ} \mathrm{C}$, and 40 repetitive cycles of 15 sec at $95^{\circ} \mathrm{C}, 30 \mathrm{sec}$ at $62^{\circ} \mathrm{C}$, and $30 \mathrm{sec}$ at $72^{\circ} \mathrm{C}$, followed by a $7 \mathrm{~min}$ final extension at $72^{\circ} \mathrm{C}$. 
Positive (previously known blood DNA from a E. canis-infected dog) and negative (water) controls were included in all PCR assays.

To amplify a 665-bp fragment of the Borrelia flagellin (flaB) gene, a initial PCR reaction using primers FLA LL (5'- ACA TAT TCA GAT GCA GAC AGA GGT - 3') and FLA RL (5’-GCA ATC ATA GCC ATT GCA GAT TGT - 3’) were employed, and for the nested-PCR that amplifies a 354-bp, primers FLA RS (5 - CTT TGA TCA CTT ATC ATT CTA ATA GC - 3`) and FLA LS (5`- AAC AGC TGA AGA GCT TGG AAT G - 3`) were used, with minor modifications. ${ }^{34}$ PCR were carried out in a total of $50 \mu \mathrm{L}$ solution containing 1X PCR buffer minus $\mathrm{Mg}, 1.5 \mathrm{mM} \mathrm{MgCl} 2,0.2 \mathrm{mM}$ dNTPs, $1 \mathrm{U}$ of Platinum TaqDNA Polymerase (Invitrogen, Carlsbad, CA), and $0.2 \mu \mathrm{M}$ of each primer. For all PCR reactions, one positive control (DNA extracted from Borrelia anserina culture) and two negative controls (water) were included. Cycling conditions for both reactions included a initial denaturation for $3 \mathrm{~min}$ at $95^{\circ} \mathrm{C}$, and 40 repetitive cycles of $1 \mathrm{~min}$ at $95^{\circ} \mathrm{C}, 1 \mathrm{~min}$ at $65^{\circ} \mathrm{C}$, and 1 min at $75^{\circ} \mathrm{C}$, followed by a 10 min final extension at $75^{\circ} \mathrm{C}$.

PCR to identify Babesia spp was performed using primers BAB-33-57 (5' - GCC AGT AGT CAT ATG CTT GTC TTAA -3') and BAB-432-409 (5'- TTC CTT AGA TGT GGT AGC CGT TTC -3'), corresponding to conserved regions of the 18S rRNA gene of Babesia spp, designed to amplify a $\approx 370$-bp portion of the $18 \mathrm{~S}$ rRNA gene. PCR were carried out in a total of $50 \mu \mathrm{L}$ solution containing 1X PCR buffer minus $\mathrm{Mg}, 1.5 \mathrm{mM} \mathrm{MgCl} 2,0.2 \mathrm{mM}$ dNTPs, $1 \mathrm{U}$ of Platinum TaqDNA Polymerase (Invitrogen, Carlsbad, CA), and $0.2 \mu \mathrm{M}$ of each primer. Positive (previously known DNA from a B. canis-infected dog) and negative (water) controls were included in all PCR assays. PCR cycle conditions consisted of an initial denaturation for 3 min at $95^{\circ} \mathrm{C}$, and 40 repetitive cycles of $15 \mathrm{sec}$ at $95^{\circ} \mathrm{C}, 30 \mathrm{sec}$ at $63^{\circ} \mathrm{C}$, and $30 \mathrm{sec}$ at $72^{\circ} \mathrm{C}$, followed by a 7 min final extension at $72^{\circ} \mathrm{C}$. The 
PCR-positive samples were purified using ExoSap (USB) and sequenced in an automatic sequencer (Applied Biosystems/PerkinElmer, model ABI Prism 310 Genetic, CA, US) according to the manufacturer`s protocol. Partial sequences obtained were submitted to BLAST analysis to determine similarities to other species. ${ }^{35}$

Indirect ELISA to B. burgdorferi. Antigen preparation was performed as previously described. ${ }^{36}$ Indirect ELISA using antigens of B. burgdorferi G 39/40, North America origin, was performed by standard method with minor modifications to human samples, and exactly as described when performed to the canine sera samples. ${ }^{36,37}$ Anti-dog IgG conjugated with alkaline phosphatase produced in rabbit (Sigma-Aldrich, St. Louis, MO) was added in a 1:1000 dilution in blocking solution. Sera of 8 dogs from an urban area of São Paulo, without tick-bite history and without visiting rural areas were used as negative controls. As positive control of the reaction, a previously known positive dog serum was used. The same method was applied to the human sera samples, but in this case both IgG and IgM were assayed as previously described. ${ }^{38}$ Anti-human IgG and Anti-human IgM, both alkaline phosphatase conjugated (Sigma) were diluted 1:1000 in blocking solution. Eight negative human sera samples from people that did not report previous tick-bite and no clinical signs were used as negative controls. As positive control, a known positive human serum to $B$. burgdorferi antigen was used.

Indirect ELISA to horse sera was performed as described, with modifications. ${ }^{39}$ Plates were coated with $B$. burgdorferi antigen in a concentration of $15 \mu \mathrm{g} / \mathrm{ml}$ diluted in Carbonate buffer $(\mathrm{pH}=9,6)$. Tween $80(0.05 \%)$ was applied contrary to Tween 20 . Blocking buffer was made with 5\% skim milk diluted in PBS Tween 80 (pH=7.4). All serum samples (including eight negative controls) were used in a dilution of 1:400, and positive control was titrated using a two-fold dilution, starting at 1:400. Anti-horse IgG alkaline phosphatase conjugated (Sigma) was diluted 1:15000 in the PBS Tween 80 buffer, and plates were incubated for 60 
min in a wet chamber at room temperature. Thereafter, washing procedures were employed and substrate was applied as previously described. Plates were read at $405 \mathrm{~nm}$ in a Titertek Multiscan MCC/340 (Flow Laboratories), and when the first dilution of the positive control serum reached the optical density value near 1.0, the reaction was ready to be read. Cut-off value was established with a confidence degree of $99.9 \%$ obtained by considering the mean optical density plus three standard deviations of the eight negative control sera. Optical densities higher than cut-off values were considered positive and the titers were estimated by regression curve.

Immunofluorescence assay (IFA) to Rickettsia spp. IFA slides were prepared using 12-well slides containing crude antigens derived from six Rickettsia isolates from Brazil: $R$. rickettsii strain Taiaçu, $R$. parkeri strain At24, $R$. bellii strain Mogi das Cruzes, $R$. amblyommii strain Ac37, R. rhipicephali strain HJ5 and R. felis strain Pedreira. Slides were prepared as previously described. ${ }^{40}$ Human, canine and horse sera were diluted in twofold increments with PBS starting from 1:64 dilution. Ten microliters of the diluted sera were added to each well of the antigen slides. Slides were incubated at $37^{\circ} \mathrm{C}$ for 30 minutes in a humid chamber. The slides were rinsed once, and then washed twice for 10 minutes per wash in PBS. Incubation of the slides was performed with fluorescein isothiocyanate-labeled goat anti-human IgG, goat anti-dog IgG or goat anti-horse IgG (IgG; Sigma Diagnostics, St. Louis, MO), and washed as described above. The slides were mounted with buffered glycerin under coverslips. In each slide, a serum previously shown to be nonreactive (negative control) and a known reactive serum (positive control) were tested. For each sample, the endpoint titer reaction with each of the six rickettsial antigens was determined. Slides were read in an ultraviolet microscope (Olympus BX60, Japan) at 400X magnification.

IFA to Ehrlichia canis. Individual serum samples were tested using E. canis-infected DH82 cells as antigen, performed with a Brazilian strain (strain São Paulo) isolated from a 
naturally infected dog. ${ }^{12}$ A fluorescein-conjugated anti-dog IgG (Sigma) previous titrated to the best working dilution (1:600) was used as described. ${ }^{12,41}$ To the human sera, anti-human IgG fluorescein-conjugated (Sigma) was employed in the 1:400 dilution. Serum was considered to contain antibodies reactive to E. canis if it displayed a reaction at the 1:64 dilution. Blocking solution (BSA 1\% in PBS for canine sera, and inactivated rabbit sera $2 \%$ in PBS for human sera) were used to diminish background. In each slide, a serum previously shown to be nonreactive (negative control) and a known reactive serum (positive control) were tested. Samples that reacted at the screening dilution (1:64) were titrated using serial two-fold dilutions to determine endpoint titers.

IFA to Babesia spp and Theileria equi. Antigens of Babesia canis, Babesia bovis, and T. equi were prepared as described (Furuta PI and others, Madruga CR and others, unpublished data). ${ }^{42}$ Briefly, serum dilution tested against Babesia canis was 1:40, and to $B$. bovis and T. equi was 1:80. After washing with PBS buffer, slides were incubated with the corresponding fluorescein-conjugate. Anti-horse IgG FITC (Sigma) was diluted 1:32; antidog IgG FITC (Sigma) was diluted 1:200; and anti-human IgG FITC (Sigma) was diluted $1: 400 .^{43}$

\section{RESULTS AND DISCUSSION}

Results of all serological tests and PCR performed on human, dog, and horse blood samples are shown in Table 1. Data were separated according to rural and urban areas. In addition, results for the Agro-Technical school were presented separately because half of the human samples were collected from this single site.

Human samples were all negative for Babesia, both by serology and PCR. A few human or horse sera were reactive for B. burgdorferi by serology. On the other hand, 
approximately half of the dogs were serologically reactive to B. burgdorferi, suggesting the participation of dogs and their ticks in the epidemiological cycle of BYS in Brazil. Differing from the US, Europe and Asia, no Ixodes ricinus-complex ticks are present in Brazilian BYSendemic areas. Maximum titers achieved to B. burgdorferi in human samples were 1:800 for IgG and 1:200 for IgM. In Brazil, serology to B. burgdorferi usually presents low titers that decrease to disappearance fast. Spirochetes have never been isolated from humans or ticks. For these reasons, the disease presented in the country, which reproduces most of the clinical symptoms of the classical Lyme Disease, receives another nomenclature. Recent studies from the BYS reference laboratory suggest that the etiological agent of this disease can be a modified spirochete at its morphological or genetic aspects, and that these changes have happened due to the lack of I. ricinus-complex ticks in BYS-endemic areas, differences in the biodiversity and climate of Brazil (N.H.Y., unpublished data)

Overall, sera from $70(34.8 \%)$ humans, 7 (7.6\%) dogs, and 7 (25.9\%) horses were reactive to at least one Rickettsia species. Endpoint titers of human sera varied from 64 to 1024 to all six Rickettsia species. Endpoint titers of dog sera varied from 64 to 32768 for $R$. rickettsii, 256 to 16384 for $R$. parkeri, 64 to 4096 for $R$. amblyommii, $R$. rhipicephali, $R$. bellii, and $R$. felis. Endpoint titers of horse sera varied from 64 to 512 for $R$. rickettsii, 64 to 128 for $R$. parkeri and R. felis, 128 to 1024 for $R$. amblyommii, and 128 to 512 to $R$. rhipicephali and $R$. bellii. Considering individual sera, in all cases endpoint titers for two or more Rickettsia species were less than 4-fold different, except for one case, a dog from a household in the rural area of Santa Leopoldina municipality, which presented endpoint titer of 1024 to R. felis, 128 to R. bellii, and non-reactive for the remaining Rickettsia species. Due to this greater difference between titers, the serological response in this dog was considered to be elicited by $R$. felis. In fact, $R$. felis-infected fleas (Ctenocephalides felis felis) collected on dogs were also observed in both urban and rural areas of the present study (Labruna MB and 
others, unpublished data). These results suggest that part of the serologically-reactive human sera of the present study could indicate past infection by $R$. felis.

Our serological results, coupled with molecular assays, indicate that a significant amount of dogs were infected by E. canis. Although no human blood showed to contain ehrlichial DNA, at least $2 \%$ of the human sera were reactive to E. canis antigen by IFA. Since E. canis has been shown to infect humans in Venezuela, these serological responses to $E$. canis in the present study could represent accidental infection by $E$. canis, since $R$. sanguineus was a common finding on dogs of the households of both urban and rural areas of the present study. ${ }^{44,45}$

For most of the agents investigated, similar results were obtained for urban and rural humans and dogs. One could find these results unexpectable because urban and rural areas have lots of ecological differences, although in all selected municipalities, separation of the urban and rural environments is very tenuous. However, all urban households of the present study were selected because of recent history of Lyme Disease-like Syndrome among residents. In this case, they all claimed about previous tick infestations when visiting rural areas (data not shown).

Both human and horse samples from the Agro-Technical School demonstrated serological positive reactions to the six Rickettsia species, in contrast to canine samples that showed no reaction. In 2005, the death of two humans from the school was assumed to be caused by a SFG Rickettsia (unpublished data from the State of Espírito Santo Health Secretary). The majority of people from the school, sampled for this study, reported frequent tick bites within the school area. Part of these ticks were collected by us and identified as Amblyomma cajennense and Amblyomma dubitatum (data not shown). Possibly, the few dogs sampled in the school are less exposed to these ticks, since they were housed close to the main 
buildings, far from the tick-infested fields where the students regularly had field classes and horses were used during work.

Assembling our results, we can infer that the north part of the State of Espírito Santo can be considered an endemic area for SFG Rickettsia but no former considerations can be made about the other organisms regarding human population, although in domestic animals it was possible to conclude that Ehrlichia canis and Babesia spp. were circulating while we surveyed these places, contributing to the conclusion that these areas are endemic to some other tick-borne diseases in animals. Hepatozoon canis was also found infecting dogs, as previously described. ${ }^{45}$ Further studies using this example of survey in other parts of Brazil would contribute for the best elucidation on tick-borne zoonoses.

Acknowledgments: We are grateful to Melanie Gutjahr (Laboratory of Epidemiology of the Faculty of Veterinary Medicine of the University of São Paulo) for preparing the Figure 1 of the present study, Denise M. Mancini [Coordenação Geral de Laboratórios de Saúde Pública (CGLAB), Secretaria de Vigilância em Saúde (SVS) do Ministério da Saúde (MS)], and Regina M. B. Terrão (Lacen Espírito Santo) for logistic support in Espírito Santo, and to the "Agentes Locais de Vigilância Ambiental em Saúde do Departamento de Vigilância Ambiental do Município de Nova Venécia, ES” for their valuable help during field work.

Financial Support: This work was supported by the Fundação de Amparo a Pesquisa do Estado de São Paulo (FAPESP grant 07/51899-2 to N.H.Y.), Coordenação de Aperfeiçoamento de Pessoal de Nível Superior (CAPES PhD scholarship to M.G.S.) and Conselho Nacional de Desenvolvimento Científico e Tecnológico (CNPq career scholarship to M.B.L.). 
Authors’ addresses: Mariana G. Spolidorio, Laboratório de Investigação Médica 17 (LIM17), Faculdade de Medicina, Universidade de São Paulo, Av. Doutor Arnaldo 455, sala 3184, Cerqueira César, São Paulo, SP, 01246-903, Brazil. Phone: +55-11-30617496, FAX: +55-1130617490. e-mail: marianaspolidorio@gmail.com . Marcelo B. Labruna, Departamento de Medicina Veterinária Preventiva e Saúde Animal, Faculdade de Medicina Veterinária e Zootecnia, Universidade de São Paulo, Av. Prof. Orlando Marques de Paiva 87, Cidade Universitária, São Paulo, SP, 05508-270, Brazil. Phone: +55-11-30911394, FAX: +55-113091 7928, e-mail: labruna@usp.br. Rosangela Z. Machado, Departamento de Patologia Veterinária, Faculdade de Ciências Agrárias e Veterinárias, Universidade Estadual Paulista "Julio de Mesquita Filho", Via de Acesso Prof. Paulo Donato Castellane km 5 S/No, Jaboticabal, SP, 14884-900, Brazil. Phone: +55-16-32092662, FAX: +55-16-32024275, email: zacarias@fcav.unesp.br . Jonas Moraes-Filho, Departamento de Medicina Veterinária Preventiva e Saúde Animal, Faculdade de Medicina Veterinária e Zootecnia, Universidade de São Paulo, Av. Prof. Orlando Marques de Paiva 87, Cidade Universitária, São Paulo, SP, 05508-270, Brazil. Phone: +55-11-30911446, FAX: +55-11-3091 7928, e-mail: jonasmfilho@hotmail.com . Augusto Marchon Zago, Núcleo de Vigilância em Saúde, Superintendência Regional de Saúde de Colatina, Rua Aroldo Antolini, s/nº , Prédio do INSS, Sala 214, Colatina, ES, 29702-080, Brazil. Phone/FAX: +55-27-37211945, e-mail: augustozago@saude.es.gov.br . Dirlei Molinari Donatele, Centro Universitário São Camilo Espírito Santo - CUSC, Rua São Camilo de Léllis, 01, Cachoeiro de Itapemirim, ES, 29304910, Brazil. Phone/FAX: +55-28-35528960. Iara Silveira, Departamento de Medicina Veterinária Preventiva e Saúde Animal, Faculdade de Medicina Veterinária e Zootecnia, Universidade de São Paulo, Av. Prof. Orlando Marques de Paiva 87, Cidade Universitária, São Paulo, SP, 05508-270, Brazil. Phone: +55-11-30911446, FAX: +55-11-3091 7928, email: iarasilv@yahoo.com.br . Késia Margotto Caliari, Núcleo de Vigilância em Saúde, 
Superintendência Regional de Saúde de Colatina, Rua Aroldo Antolini, s/nº Prédio do INSS,

Sala 214, Colatina, ES, 29702-080, Brazil. Phone: +55-27-37225187, FAX: +55-2731777922, e-mail: kesiamargotto@saude.es.gov.br . Natalino H. Yoshinari, Laboratório de Investigação Médica 17 (LIM17), Faculdade de Medicina, Universidade de São Paulo, Av. Doutor Arnaldo 455, sala 3184, Cerqueira César, São Paulo, SP, 01246-903, Brazil. Phone: (+5511) 30617496 / FAX: (+5511) 30617490. e-mail: yoshinari@lim17.fm.usp.br .

\section{REFERENCES}

1. Dias E, Martins AV, 1939. Spotted fever in Brazil. A summary. Am J Trop Med. 19:103-108.

2. Piza JT, Meyer JR, Gomes LS, 1993. Typho exantematico de São Paulo. São Paulo: Sociedade Impressora Paulista.

3. Galvão MAM, Silva LJ, Nascimento EMM, Calic SB, Sousa R, Bacellar F, 2005. Riquetsioses no Brasil e Portugal: ocorrência, distribuição e diagnóstico. Rev Saúde Pública 39(5): 850--856.

4. Angerami RN, Resende MR, Feltrin AF, Katz G, Nascimento EM, Stucchi RS, Silva LJ, 2006. Brazilian spotted fever: a case series from an endemic area in southeastern Brazil: epidemiological aspects. Ann N Y Acad Sci 1078: 170--172.

5. Lamas C, Favacho A, Rozental T, Bóia MN, Kirsten AH, Guterres A, Barreira J, de Lemos ER, 2008. Characterization of Rickettsia rickettsii in a case of fatal Brazilian spotted fever in the city of Rio de Janeiro, Brazil. Braz J Infect Dis 12(2): 149--151.

6. Labruna MB, 2009. Ecology of Rickettsia in South America. Ann N Y Acad Sci 1166: $156--166$. 
7. Sexton DJ, Muniz M, Corey GR, Breitschwerdt EB, Hegarty BC, Dumler S, Walker DH, Pecanha PM, Dietze R, 1993. Brazilian spotted fever in Espirito Santo, Brazil: description of a focus of infection in a new endemic region. Am J Trop Med Hyg 1993 49(2): 222-226.

8. Oliveira KA, Oliveira LS, Dias CC, Silva A Jr, Almeida MR, Almada G, Bouyer DH, Galvão MA, Mafra C, 2008. Molecular identification of Rickettsia felis in ticks and fleas from an endemic area for Brazilian Spotted Fever. Mem Inst Oswaldo Cruz 103(2): 191-194.

9. Mantovani E, Costa IP, Gauditano G, Bonoldi VL, Higuchi ML, Yoshinari NH, 2007. Description of Lyme disease-like syndrome in Brazil. Is it a new tick borne disease or Lyme disease variation? Braz J Med Biol Res 40(4): 443--456.

10. Dumler JS, Barbet AF, Bekker CP, Dasch GA, Palmer GH, Ray SC, Rikihisa Y, Rurangirwa FR, 2001. Reorganization of genera in the families Rickettsiaceae and Anaplasmataceae in the order Rickettsiales: unification of some species of Ehrlichia with Anaplasma, Cowdria with Ehrlichia and Ehrlichia with Neorickettsia, descriptions of six new species combinations and designation of Ehrlichia equi and 'HGE agent' as subjective synonyms of Ehrlichia phagocytophila. Int J Syst Evol Microbiol 51(6): 2145--2165.

11. Torres HM, Massard CL, Figueiredo MJ, Ferreira T, Almosny NRP, 2002. Isolamento e propagação da Ehrlichia canis em células DH82 e obtenção de antígeno para a reação de imunofluorescência indireta. Rev Bras Ciênc Vet 9: 77--82.

12. Aguiar DM, Saito TB, Hagiwara MK, Machado RZ, Labruna MB, 2007. Serological diagnosis of canine monocytic ehrlichiosis with Brazilian antigen of Ehrlichia canis. Cienc. Rural 37: 796--802.

13. Labruna MB, McBride JW, Camargo LM, Aguiar DM, Yabsley MJ, Davidson WR, Stromdahl EY, Williamson PC, Stich RW, Long SW, Camargo EP, Walker DH, 2007. A 
preliminary investigation of Ehrlichia species in ticks, humans, dogs, and capybaras from Brazil. Vet Parasitol 143(2): 189--195.

14. Machado RZ, Duarte JM, Dagnone AS, Szabó MP, 2006. Detection of Ehrlichia chaffeensis in Brazilian marsh deer (Blastocerus dichotomus). Vet Parasitol 139(1-3): $262--266$.

15. Oliveira LS, Oliveira KA, Mourão LC, Pescatore AM, Almeida MR, Conceição LG, Galvão MA, Mafra C, 2009. First report of Ehrlichia ewingii detected by molecular investigation in dogs from Brazil. Clin Microbiol Infect Epub ahead of print.

16. Calic SB, Galvão MA, Bacellar F, Rocha CM, Mafra CL, Leite RC, Walker DH., 2004. Human ehrlichioses in Brazil: first suspect cases. Braz J Infect Dis 8(3): 259--262.

17. Costa PS, Valle LM, Brigatte ME, Greco DB, 2006. More about human monocytotropic ehrlichiosis in Brazil: serological evidence of nine new cases. Braz J Infect Dis 10(1): 7-10.

18. Passos LM, Geiger SM, Ribeiro MF, Pfister K, Zahler-Rinder M, 2005. First molecular detection of Babesia vogeli in dogs from Brazil. Vet Parasitol 127(1): 81--85.

19. Trapp SM, Messick JB, Vidotto O, Jojima FS, de Morais HS, 2006. Babesia gibsoni genotype Asia in dogs from Brazil. Vet Parasitol 141(1-2): 177--180.

20. Costa-Júnior LM, Ribeiro MF, Rembeck K, Rabelo EM, Zahler-Rinder M, Hirzmann J, Pfister K, Passos LM, 2009. Canine babesiosis caused by Babesia canis vogeli in rural areas of the State of Minas Gerais, Brazil and factors associated with its seroprevalence. Res Vet Sci 86(2): 257--260.

21. O'Dwyer LH, Lopes VV, Rubini AS, Paduan Kdos S, Ribolla PE, 2009. Babesia spp. infection in dogs from rural areas of São Paulo State, Brazil. Rev Bras Parasitol Vet $18(2): 23--26$. 
22. Friedhoff KT, 1982. Piroplasmas of horses - impact on the international horse trade. Berl Munch Tierarztl Wochenschr 95(19): 368--374.

23. Hildebrandt A, Hunfeld KP, Baier M, Krumbholz A, Sachse S, Lorenzen T, Kiehntopf M, Fricke HJ, Straube E, 2007. First confirmed autochthonous case of human Babesia microti infection in Europe. Eur J Clin Microbiol Infect Dis 26(8): 595--601.

24. Hunfeld KP, Hildebrandt A, Gray JS, 2008. Babesiosis: recent insights into an ancient disease. Int J Parasitol 38(11): 1219--1237.

25. Herwaldt BL, Cacciò S, Gherlinzoni F, Aspöck H, Slemenda SB, Piccaluga P, Martinelli G, Edelhofer R, Hollenstein U, Poletti G, Pampiglione S, Löschenberger K, Tura S, Pieniazek NJ, 2003. Molecular characterization of a non-Babesia divergens organism causing zoonotic babesiosis in Europe. Emerg Infect Dis (8): 942--948.

26. Alecrim I, Pinto B, Avila T, Costa R, Pessoa I, 1983. Registro do primeiro caso de infecção humana por Babesia spp. no Brasil. Rev Patol Trop 12: 11--29.

27. Ríos L, Alvarez G, Blair S, 2003. Serological and parasitological study and report of the first case of human babesiosis in Colombia. Rev Soc Bras Med Trop 36 (4): 493--498.

28. Humiczewska M, Kuźna-Grygiel W, 1997. A case of imported human babesiosis in Poland. Wiad Parazytol 43(2): 227--229.

29. Yoshinari NH, Abrão MG, Bonoldi VL, Soares CO, Madruga CR, Scofield A, Massard CL, da Fonseca AH, 2003. Coexistence of antibodies to tick-borne agents of babesiosis and Lyme borreliosis in patients from Cotia county, State of São Paulo, Brazil. Mem Inst Oswaldo Cruz 98(3): 311--318.

30. Rech A, Bittar CM, de Castro CG, Azevedo KR, dos Santos RP, Machado AR, Schwartsmann G, Goldani L, Brunetto AL, 2004. Asymptomatic babesiosis in a child with hepatoblastoma. J Pediatr Hematol Oncol 26(3): 213. 
31. Anderson BE, Sumner JW, Dawson JE, Tzianabos T, Greene CR, Olson JG, Fishbein DB, Olsen-Rasmussen M, Holloway BP, George EH, 1992. Detection of the etiologic agent of human ehrlichiosis by polymerase chain reaction. J Clin Microbiol 30(4): 775--780.

32. Breitschwerdt EB, Hegarty BC, Hancock SI, 1998. Sequential evaluation of dogs naturally infected with Ehrlichia canis, Ehrlichia chaffeensis, Ehrlichia equi, Ehrlichia ewingii, or Bartonella vinsonii. J Clin Microbiol 36(9): 2645--2651.

33. Aguiar DM, Hagiwara MK, Labruna MB, 2008. In vitro isolation and molecular characterization of an Ehrlichia canis strain from São Paulo, Brazil. Braz J Microbiol 39: 489--493.

34. Stromdahl EY, Williamson PC, Kollars TM Jr, Evans SR, Barry RK, Vince MA, Dobbs NA, 2003. Evidence of Borrelia lonestari DNA in Amblyomma americanum (Acari: Ixodidae) removed from humans. J Clin Microbiol 41(12): 5557--5562.

35. Altschul SF, Gish W, Miller W, Myers EW, Lipman DJ, 1990. Basic local alignment search tool. J Mol Biol 215: 403--410.

36. Joppert AM, Hagiwara MK, Yoshinari NH, 2001. Antibodies in dogs from Cotia county, São Paulo State, Brazil. Revta Inst Med Tropical 43(5): 251--255.

37. Voller A, Bidwell DE, Bartlett A, 1976. Enzyme immunoassays in diagnostic medicine. Theory and practice. Bull World Health Organ 53(1): 55--65.

38. Naka EN, Costa IP, Arão CAB, Soares CO, Yoshinari NH, 2008. Pesquisa de anticorpos anti-Borrelia e anti-Babesia em soro de crianças com manifestações clínicas e epidemiologia compatíveis com a doença de Lyme-Simile no Estado de Mato Grosso do Sul. Rev Bras Reumatol 48: 74--85.

39. Salles RS, Fonseca AH, Scofield A, Madureira RC, Yoshinari NH, 2002. Sorologia para Borrelia burgdorferi latu sensu em eqüinos no estado do Rio de Janeiro. Hora Vet 127: 46--49. 
40. Labruna MB, Horta MC, Aguiar DM, Cavalcante GT, Pinter A, Gennari SM, Camargo LM, 2007. Prevalence of Rickettsia infection in dogs from the urban and rural areas of Monte Negro municipality, western Amazon, Brazil. Vector Borne Zoonotic Dis 7(2): $249--225$.

41. Ristic M, Huxsoll DL, Weisiger RM, Hildebrandt PK, Nyindo MB, 1972. Serological diagnosis of tropical canine pancytopenia by indirect immunofluorescence. Infect Immun 6(3): 226--231.

42. Baldani CD, Machado RZ, Raso TF, Pinto AA, 2007. Serodiagnosis of Babesia equi in horses submitted to exercise stress. Pesq Vet Bras 27(4): 179--183.

43. Callow LL, McGregor W, Rodwell BJ, Rogers RJ, Fraser GC, Mahoney DF, Robertson GM, 1979. Evaluation of an indirect fluorescent antibody test to diagnose Babesia equi infection in horses. Aust Vet J 55(12): 555--559.

44. Perez M, Bodor M, Zhang C, Xiong Q, Rikihisa Y, 2006. Human infection with Ehrlichia canis accompanied by clinical signs in Venezuela. Ann N Y Acad Sci 1078: 110--117.

45. Spolidorio MG, Labruna MB, Zago AM, Donatele DM, Caliari KM, Yoshinari NH, 2009. Hepatozoon canis infecting dogs in the State of Espírito Santo, southeastern Brazil. Vet Parasitol 163(4): 357--361. 


\section{Table 1}

Results of serological tests and PCR performed on blood samples of humans, dogs, and horses from six municipalities in the state of Espírito

Santo, southeastern Brazil.

\begin{tabular}{|c|c|c|c|c|c|c|c|c|c|c|c|}
\hline \multirow{3}{*}{ Agents investigated } & \multicolumn{11}{|c|}{ No. individuals that showed to be positive (\%) } \\
\hline & \multicolumn{4}{|c|}{ Humans } & \multicolumn{4}{|c|}{ Dogs } & \multicolumn{3}{|c|}{ Horses } \\
\hline & $\begin{array}{c}\text { Rural } \\
(n=100)\end{array}$ & $\begin{array}{l}\text { Urban } \\
(n=9)\end{array}$ & $\begin{array}{l}\text { School } \\
(n=92)\end{array}$ & $\begin{array}{c}\text { Total } \\
(n=201)\end{array}$ & $\begin{array}{l}\text { Rural } \\
(n=71)\end{array}$ & $\begin{array}{l}\text { Urban } \\
(n=14)\end{array}$ & $\begin{array}{l}\text { School } \\
(n=7)\end{array}$ & $\begin{array}{l}\text { Total } \\
(n=92)\end{array}$ & $\begin{array}{l}\text { Rural } \\
(n=24)\end{array}$ & $\begin{array}{l}\text { School } \\
(n=3)\end{array}$ & $\begin{array}{l}\text { Total } \\
(n=27)\end{array}$ \\
\hline \multicolumn{12}{|l|}{ Serology } \\
\hline Borrelia burgdorferi & $8(8.0)$ & $1(11.1)$ & $0(0)$ & $9(4.5)$ & $38(53.5)$ & $7(50.0)$ & $2(28.6)$ & $47(51.1)$ & $1(4.2)$ & $0(0)$ & $0(0)$ \\
\hline Rickettsia rickettsii & $31(31.0)$ & $2(22.2)$ & $16(17.4)$ & $49(24.3)$ & $4(5.6)$ & $0(0)$ & $0(0)$ & $4(4.3)$ & $4(16.7)$ & $3(100)$ & $7(25.9)$ \\
\hline R. parkeri & $28(28.0)$ & $2(22.2)$ & $21(22.8)$ & $41(20.4)$ & $2(2.8)$ & $0(0)$ & $0(0)$ & $2(2.2)$ & $2(8.3)$ & $2(66.7)$ & $4(14.8)$ \\
\hline R. amblyommii & $33(33.3)$ & $3(33.3)$ & $16(17.4)$ & $52(25.9)$ & $3(4.2)$ & $0(0)$ & $0(0)$ & $3(3.3)$ & $3(2.5)$ & $2(66.7)$ & $5(18.5)$ \\
\hline R. rhipicephali & $36(36.0)$ & $4(44.4)$ & $17(18.5)$ & $57(28.3)$ & $2(2.8)$ & $1(7.1)$ & $0(0)$ & $3(3.3)$ & $3(2.5)$ & $2(66.7)$ & $5(18.5)$ \\
\hline R. felis & $31(31.0)$ & $4(44.4)$ & $16(17.5)$ & $51(25.3)$ & $2(2.8)$ & $2(14.3)$ & $0(0)$ & $4(4.3)$ & $1(4.2)$ & $2(66.7)$ & $4(14.8)$ \\
\hline R. bellii & $17(17.0)$ & $2(22.2)$ & $10(10.9)$ & $39(19.4)$ & $3(4.2)$ & $1(7.1)$ & $0(0)$ & $4(4.3)$ & $2(8.3)$ & $3(100)$ & $5(18.5)$ \\
\hline Ehrlichia canis & $3(3.0)$ & $0(0)$ & $1(1.1)$ & $4(2.0)$ & $33(46.5)$ & $4(28.6)$ & $1(14.3)$ & $38(41.3)$ & ND & ND & - \\
\hline Babesia canis vogeli & $0(0)$ & $0(0)$ & $0(0)$ & $0(0)$ & $25(46.5)$ & $6(42.9)$ & $0(0)$ & $31(33.7)$ & ND & ND & - \\
\hline
\end{tabular}




\begin{tabular}{|c|c|c|c|c|c|c|c|c|c|c|c|}
\hline Babesia bovis & $0(0)$ & $0(0)$ & $0(0)$ & $0(0)$ & ND & ND & ND & - & ND & ND & - \\
\hline Theileria equi & $0(0)$ & $0(0)$ & $0(0)$ & $0(0)$ & $0(0)$ & $0(0)$ & $0(0)$ & $0(0)$ & $24(100)$ & $3(100)$ & $27(100)$ \\
\hline \multicolumn{12}{|l|}{ PCR } \\
\hline Anaplasmataceae & $0(0)$ & $0(0)$ & $0(0)$ & $0(0)$ & $22(31.0)$ & $3(21.4)$ & $0(0)$ & $25(27.2)$ & $0(0)$ & $0(0)$ & $0(0)$ \\
\hline Borrelia & $0(0)$ & $0(0)$ & $0(0)$ & $0(0)$ & $0(0)$ & $0(0)$ & $0(0)$ & $0(0)$ & $0(0)$ & $0(0)$ & $0(0)$ \\
\hline Babesia/Theileria & $0(0)$ & $0(0)$ & $0(0)$ & $0(0)$ & $14(19.7)$ & $6(42.9)$ & $0(0)$ & $20(21.7)$ & $6(25.0)$ & $0(0)$ & $6(22.2)$ \\
\hline Hepatozoon* & ND & ND & ND & - & $46(64.8)$ & $8(57.1)$ & $0(0)$ & $54(58.7)$ & ND & ND & - \\
\hline
\end{tabular}

*Previously reported data. ${ }^{45}$ 


\section{FIGURE LEGEND}

Fig. 1. Location of six counties in the state of Espírito Santo, southeastern Brazil, where samples were collected for the present study.

\section{CORRESPONDENCE ADDRESS}

Mariana G. Spolidorio, Av. Doutor Arnaldo, 455, sala 3184, Bairro Cerqueira César, São

Paulo - SP, CEP 01246-903, Brazil. marianaspolidorio@gmail.com

Phone: +55 11 3061-7496 / FAX: +55 11 3061-7490 


\title{
ANEXO 2
}

Veterinary Parasitology 163 (2009) 357-361

Short communication

\section{Hepatozoon canis infecting dogs in the State of Espírito Santo, southeastern Brazil}

\author{
Mariana G. Spolidorio ${ }^{\mathrm{a}, *}$, Marcelo B. Labruna ${ }^{\mathrm{b}}$, Augusto M. Zago ${ }^{\mathrm{c}}$, Dirlei M. Donatele ${ }^{\mathrm{d}}$, \\ Késia M. Caliari ${ }^{c}$, Natalino H. Yoshinari ${ }^{a}$
}

'Laboratório de Imves tigą̧áo Médica 17 (LM17), Faculdade de Medicina, Universidade de Säo Paula, Av. Doutor Arnaldo 455, sala 3184, Cerqueira César. Sẩ Paulo, SP CEP 01246-903, Bruzil

'Departamento de Medicina Veterinária Preventiva e Satide Animal Faculdade de Medicina Veterinária e Zaotecria, Universidade de São Paula. Av. Prof. Orlando Marques de Pativa 87. Cidade Universitúria, Sä́o Paulo, SP 05508-270, Brazil

"Núcleo de Vigilância em Saúde, Superintendênnia Regional de Saúde de Colatina, Rua Aroldo Antoliní s/rn', Prédio do INSS, ${ }^{\circ}$ andar, Sain 214,

Bairro Esplanada, Colatina, ES CEP 29702-080, Brwil

${ }^{4}$ Centro Universitário Sâo Camilo Espirito Santo - CuSC, Rua Sâo Camilo de Léllis, 01, Paraiso, Cachoeiro de Itapemirum, ES CEP 29304-910, Brazil

\section{ARTICLE INFO}

\section{Article history:}

Received 16 Deamber 2008

Received in revised form 13 March 2009 Acrepted 6 May 2009

\section{Keywords:}

Hepatozoon anis

Dog

Rhipicephalus sanguineus

Ambiyomma cajermense

Espirito Santo

Brazil

\begin{abstract}
A BSTR A C T
From May 2007 to March 2008, blood samples were collected from 92 healthy dogs living in 21 households ( 17 farms in rural area, and 4 homes in urban area) in 6 counties of the State of Espirito Santo, southeastern Brazil. In addition, ticks were collected from these dogs. A mean of $4.4 \pm 3.0$ dogs (range: 1-12) were sampled per household; 78 and 14 dogs were from rural and urban areas, respectively. Polymerase chain reaction (PCR) designed to amplify fragments of the $18 \mathrm{~S}$ rDNA gene of Babesia spp or Hepatozoon spp reveal ed amplicons of the expected size in 20 (21.7\%) dogs for Babesia and 54 (58.7\%) dogs for Hepatozoon. All Babesia-positive dogs were also Hepatozoon-positive. Among the 21 households, 15 (71.4\%) from 3 counties had at least one PCR-positive dog, including 13 farms (rural area) and 2 homes (urban area). A total of 40 PCR products from the Hepatazoon-PCR, and 19 products from the Babesia-PCR were submitted to DNA sequencing. All generated sequences from HepatozoonPCR were identical to each other, and to corresponding $18 \mathrm{~S}$ rDNA sequences of $H$. canis in GenBank. Surprisingly, all generated sequences from the Babesia PCR were also identical to corresponding $18 \mathrm{~S}$ rDNA sequences of $\mathrm{H}$. canis in GenBank. Dogs from 10 rural and 2 urban households were found infested by Rhipicephalus sanguineus ticks. Immature of Amblyomma cajennense ticks were found in dogs from only 4 rural households (also infested by $R$. sanguinetus). All but one household with $R$. sanguineus-infested dogs had at least one Hepatozoon-infected dog. Statistical analysis showed that the presence of ticks (i.e $R$ sanguineus) infesting dogs in the households was significantly $(P<0.05)$ associated with at least one PCR-positive dog. There was no significant association $(P>0.05)$ between PCRpositive dogs and urban or rural households. Canine hepatozoonosis caused by $H$ canis is a high frequent infection in Espirito Santo, Brazil, where it is possibly vectored by $R$ sanguineus. Since all infected dogs were found apparently heal thy, the pathogenicity of $H$. canis fordogs in Espirito Santo is yet to be elucidated.
\end{abstract}

(6) 2009 Elsevier B.V. All rights reserved.
- Corresponding author. Tel.: +551130617496 ; fax: +551130617490 .
E-mail address: marianaspolidorioegmail.com (M.G. Spolidorio).

304-4017/5 - see front matter 02009 Elsevier B.V. All rights reserved.

doi:10.1016/j.vetpar.2009.05.002

\section{Introduction}

Canine hepatozoonosis is a tick-borne disease of dogs found almost worldwide, caused by two different species of apicomplexan protozoa, Hepatozoon canis and 
Hepatozoon americanum (Baneth et al., 2003; VincentJohnson, 2003). H. canis was first described in India in 1905 , and was incriminated as the cause of a mild disease, mainly characterized by anemia and lethargy (Baneth and Weigler, 1997). Dogs infected with $H$. canis generally appear healthy, since the disease is usually unapparent and subclinical, and the diagnosis is occasionally confirmed during laboratory examinations (Mundim et al., 1994; Gondim et al., 1998; Paludo et al., 2005). Immunosuppression caused by concurrent disease or other factors appear to play an important role in manifestation of clinical signs. In contrast, dogs infected with $H$. americanum typically develop severe disease (VincentJohnson, 2003). The distribution of $H$. americanum has been restricted to the United States, whereas $H$. canis has been reported in Africa, Southeast Asia, Middle East, Europe, and South America (Baneth et aL., 2003; Gavazza et al., 2003; Vincent-Johnson, 2003; Oyamada et al., 2005: Rubini et al., 2008).

In Brazil, canine hepatozoonosis was first described by Massard (1979) from dogs of a rural area in Rio de janeiro. Recent molecular studies have revealed the species $H$. canis infecting dogs from the States of São Paulo and Rio de Janeiro, and the Federal District (Brasilia) (Paludo et al., 2005: Forlano et al., 2007: Rubini et al., 2005, 2008). Clinical evaluation in infected dogs was performed in one of these studies, which revealed mild disease similar to canine hepatozoonosis previously reported in the old World (Paludo et al., 2005).

The known vector of $H$. canis in the Old World is the tick Rhipicephalus sanguineus (Baneth et al., 2001), although Haemaphysalis spp have been suggested to be possible vectors in Japan (Murata et al., 1995). In the United States, Amblyomma americanum is the only recognized tick vector of $\mathrm{H}$. americanum (Vincent-johnson, 2003). In Brazil, Amblyomma spp have been suggested as vectors of canine hepatozoonosis, although $R$. sanguineus has also been found infesting $H$. canis-infected dogs (O'Dwyer et al., 2001: Forlano et al., 2005: Rubini et al., 2008).

The present study employed molecular analysis to evaluate infection by Hepatozoon spp and Babesia spp in dogs from the State of Espirito Santo, southeastern Brazil. In addition, we evaluated the tick species that were infesting these dogs.

\section{Materials and methods}

During May 2007 to March 2008, three scientific expeditions were undertaken to the State of Espirito Santo. southeastern Brazil. In each expedition, farms in rural and homes in urban localities were visited in the six counties: Nova Venécia $\left(18^{\circ} 43^{\prime} \mathrm{S}, 40^{\circ} 24^{\prime} \mathrm{W}\right)$, São Mateus $\left(18^{\circ} 43^{\prime} \mathrm{S}\right.$, $\left.39^{\circ} 51^{\prime} \mathrm{W}\right)$, Santa Leopoldina $\left(20^{\circ} 06^{\prime} \mathrm{S}, 40^{\circ} 32^{\prime} \mathrm{W}\right)$, Ecoporanga $\left(18^{\circ} 22^{\prime} \mathrm{S}, 40^{\circ} 50^{\prime} \mathrm{W}\right)$, Colatina $\left(19^{\circ} 32^{\prime} \mathrm{S}, 40^{\circ} 37^{\prime} \mathrm{W}\right)$, and Vila Valério $\left(18^{\circ} 59^{\prime} \mathrm{S}, 40^{\circ} 22^{\prime} \mathrm{W}\right)$. A total of 92 apparently healthy dogs were sampled from 21 households (17 farms and 4 homes). These households had been previously selected for another study with tick-borne zoonoses (N.H.Y., unpublished data), so they were not randomly selected.

Canine blood samples were collected in ethylenediaminetetraacetic acid (EDTA) anticoagulant, and kept frozen at $-20^{\circ} \mathrm{C}$ until DNA extraction. DNA was extracted from each blood sample using the DNeasy Blood \& Tissue Kit (QIAGEN, Hilden, Germany), according to the manufacturer's instructions. DNA samples were eluted in $100 \mu \mathrm{L}$ of TE buffer. Five-microliter of extracted DNA was used for polymerase chain reaction (PCR)amplification. DNAse-free water was used as a negative control for the extractions and PCR assays.

Primers HEP- $1 \bmod \left(5^{\prime}\right.$-CGC GAA ATT ACC CAA TTC TA $\left.3^{\prime}\right)$ and HEP-4 ( $5^{\prime}$-TAA GGT GCT GAA GGA GTC GTT TAT- $3^{\prime}$ ), were used to amplify $\mathrm{a} \approx 670$-bp portion of the $18 \mathrm{~S}$ rRNA gene of Hepatozoon spp (Criado-Fornelio et al., 2006). Primer HEP-1mod was modified from the HEP-1 primer reported by Criado-Fornelio et al. (2006) through the insertion of the last three nucleotides (CTA), which are conserved among Hepatozoon sequences available in GenBank. This insertion was done with the intention to increase primer annealing temperature. In addition, primers BAB-33-57 (5'-GCC AGT AGT CAT ATG CTT GTC TTAA- $\left.3^{\prime}\right)$ and $B A B-432-409$ ( $5^{\prime}$-TTC CTT AGA TGT GGT AGC CGT TTC $\left.-3^{\prime}\right)$, corresponding to conserved regions of the $18 \mathrm{~S}$ rRNA gene of Babesia spp were designed to amplify $\mathrm{a} \approx 370$ bp portion of the 18S rRNA gene. Polymerase chain reactions (PCR) were carried out in a total of $50 \mu \mathrm{L}$ solution containing $1 \mathrm{X}$ PCR buffer minus $\mathrm{Mg}, 1.5 \mathrm{mM}$ $\mathrm{MgCl}_{2}, 0.2 \mathrm{mM}$ dNTPs, $1 \mathrm{U}$ of Platinum TaqDNA Polymerase (Invitrogen, Carlsbad, CA), and $0.2 \mu \mathrm{M}$ of each primer. PCR cycle conditions for Hepatozoon spp consisted of a initial denaturation for $3 \mathrm{~min}$ at $95^{\circ} \mathrm{C}$, and 40 repetitive cycles of $15 \mathrm{~s}$ at $95^{\circ} \mathrm{C}, 40 \mathrm{~s}$ at $53^{\circ} \mathrm{C}$, and $40 \mathrm{~s}$ at $72{ }^{\circ} \mathrm{C}$, followed by a 5 min final extension at $72^{\circ} \mathrm{C}$. PCR cycle conditions for Babesia spp primers consisted of a initial denaturation for 3 min at $95^{\circ} \mathrm{C}$, and 35 repetitive cycles of $15 \mathrm{~s}$ at $95^{\circ} \mathrm{C}, 30 \mathrm{~s}$ at $63^{\circ} \mathrm{C}$, and $30 \mathrm{~s}$ at $72^{\circ} \mathrm{C}$, followed by a $7 \mathrm{~min}$ final extension at $72^{\circ} \mathrm{C}$. Both cycles were previously submitted to a gradient of temperature to find the best annealing temperature to our laboratory conditions. PCR products were electrophoresed through a $1.5 \%$ agarose gel, stained with ethidium bromide, and examined by UV transillumination. Amplicons of the expected size were purified with ExoSap (USB) and sequenced in an automatic sequencer (Applied Biosystems/PerkinElmer, model ABI Prism 310 Genetic, Foster City, CA) according to the manufacturer's protocol. Partial sequences obtained were submitted to BLAST analysis (Altschul et al., 1990) to determine the closest similarities to corresponding sequences.

During blood collections, dogs were examined for the presence of ticks, which were collected and brought to the laboratory for taxonomic identification. For statistical analysis, the presence of at least one PCR-positive dog in each farm or home was analyzed qualitatively at a dichotomous level (0: farm or home with no PCR-positive dog: 1: farm or home with at least one PCR-positive dog) with the following two independent variables by univariate analysis (Fisher's Exact test): (i) presence of ticks infesting dogs in the farm or home ( 0 : absent; 1 : present); and (ii) living place ( 0 : urban area; 1 : rural area). Statistical association between variables was considered significant if $P<0.05$. All analyses were performed using the program Epilnfo (version 3.3.2). 
Table 1

Results of PCR targeting the 18S rDNA gene of Hepatozoon spp in canine blood samples from households in six counties in the State of Espirito Santo, Brazil.

\begin{tabular}{lll}
\hline County & $\begin{array}{l}\text { No. of households } \\
\text { with at least one } \\
\text { PCR-positive dog/total } \\
\text { no. of households (\%) }\end{array}$ & $\begin{array}{l}\text { No. of PCR-positive } \\
\text { dogs/total no, of } \\
\text { dogs(\%) }\end{array}$ \\
\hline Colatina & $0 / 1(0)$ & $0 / 8(0)$ \\
Ecoporanga & $1 / 1(100)$ & $2 / 3(66.6)$ \\
Nova Venécia & $10 / 13(77.0)$ & $40 / 54(74.1)$ \\
Santa Leopoldina & $0 / 1(0)$ & $0 / 12(0)$ \\
Sảo Mateus & $4 / 4(100)$ & $12 / 13(92.3)$ \\
Vila Valério & $0 / 1(0)$ & $0 / 2(0)$ \\
Total & $15 / 21(71.4)$ & $54 / 92(58.7)$ \\
\hline
\end{tabular}

\section{Results}

A mean of $4.4 \pm 3.0$ dogs (range: 1-12) were sampled per household, totalling 92 healthy dogs; 78 dogs were from farms in the rural areas, and 14 dogs were from homes in the urban area. A total of 20 (21.7\%) dogs tested positive by the Babesia-PCR protocol, whereas 54 (58.7\%) were positive by the Hepatozoon-PCR protocol. All Babesia-positive dogs were also Hepatozoon-positive. Among the 21 households, 15 (71.4\%) from 3 counties had at least one PCR-positive dog (Table 1); these included 13 farms (rural area) and 2 homes (urban area)

A total of 40 PCR products from the Hepatozoon-PCR, and 19 products from the Babesia-PCR were submitted to DNA sequencing. Care was taken to sequence products from at least 2 different dogs from all households that had 2 or more canine samples positive by PCR All generated sequences from Hepatozoon-PCR were identical to each other, and to corresponding $18 \mathrm{~S}$ rDNA sequences of $\mathrm{H}$. canis in GenBank. Surprisingly, all generated sequences from the Babesia PCR were also identical to corresponding 18S rDNA sequences of $H$. canis in GenBank. After BLAST analyses, these sequences showed a $100 \%$ homology to $H$. canis detected in fox from Spain and Slovakia, and also from two States in Brazil: Rio Grande do Sul (in Cerdocyon thous and Pseudalopex gymnocercus foxes) and Brasilia (domestic dogs). Gene Bank accession numbers of these previous isolates are AY150067, AY461375, AY471615, AY864677, DQ869309, respectively (Criado-Fornelio et al., 2006; Paludo et al., 2005; Majláthová et al., 2007).

Dogs from 10 rural and 2 urban households were found infested with $R$. sanguineus ticks. Immature of Amblyomma $\mathrm{sp}$ ticks were found in dogs from only 4 rural households (also infested with $R$. sanguineus). Samples of these immatures were reared in the laboratory until the adult stage, and were identified as Amblyomma cajennense. All but one household with $R$. sanguineus-infested dogs had at least one Hepatozoon-infected dog. By the univariate analysis, the presence of ticks (i.e. $R$ sanguineus) infesting dogs in the households was significantly $(P<0.05)$ associated with at least one PCR-positive dog. There was no significant association $(P>0.05)$ between PCR-positive dogs and urban or rural households.

\section{Discussion}

The present study showed that canine infection by $H$. canis was common among apparently healthy dogs in the State of Espírito Santo, with an overall infection rate of $58.7 \%$ This value is within previously reported infection rates among healthy rural dogs from other parts of Brazil, which varied from 39.2 to $67.7 \%$ in the States of São Paulo and Rio de Janeiro (O'Dwyer et al., 2001; Rubini et al., 2005, 2008).

Although we have tried to find Babesia DNA by PCR employing primers supposed to be specific for this protozoa genus, DNA sequencing of all amplicons of the expected size generated by these primers were shown to be $H$. canis. This 'unexpected' amplification happened in the present study because our Babesia primers have very high degree of homology with corresponding 18S rRNA sequences of Hepatozoon canis (Table 2), i.e. our primers

Table 2

Nudeotide sequence alignment for the region of the 185 rRNA gene of the apicomplexan Babesia spp and Hepatozoon canis, corresponding to primers BAB$33-57$ and $\mathrm{BAB}-432-409$.

\begin{tabular}{|c|c|c|}
\hline Apicomplexan species & Primer BAB-33-57 (forward) & Primer BAB-432-409 (reverse) \\
\hline (Genbank accession no.) & $5 '-3$ & $5,-3$, \\
\hline Primer sequence & GCCAGTAGTCATATGCTTGTCTTAA & TTCCTTAGATGTGGTAGCCGTTTC \\
\hline Babesia canis (AY072926) & $\ldots \ldots \ldots \ldots \ldots \ldots \ldots \ldots$ & $\ldots \ldots \ldots \ldots \ldots \ldots \ldots$ C. \\
\hline Babesia gibsoni (EF014475) & $\ldots \ldots \ldots \ldots \ldots \ldots \ldots$ c. & $\ldots \ldots \ldots \ldots \ldots \ldots \ldots \ldots$ \\
\hline Hepatozoon canis (AY461378) & $\ldots \ldots \ldots \ldots \ldots$ т. & $\ldots \ldots \ldots \ldots \ldots \ldots \ldots$ \\
\hline Hepatozoon canis (AY731062) & $\ldots \ldots \ldots \ldots \ldots$ т. $\ldots \ldots$ & $\ldots \ldots \ldots \ldots \ldots \ldots \ldots$ \\
\hline Hepatozoon canis (DQ439540) & 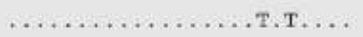 & $\ldots \ldots \ldots \ldots, \ldots, \ldots$, \\
\hline
\end{tabular}


are not Babesia genus-specific. Unfortunately, we did not do this alignment analysis before working with the Babesic primers in the present study, a procedure that would have driven us to use other primers with higher specificity for Babesia spp. Similar lack of specificity for Babesia-designed primers has been previously reported in other works where 'unexpected' Hepatozoon sequences were also generated (Oyamada et al., 2005: Majláthová et al., 2007). Probably, these authors also worked with primers showing high degree of homology with Hepatozoon canis corresponding sequences. Based on these results, it is not possible to discard the possibility of canine infection by Babesia sp in the dogs' samples in the present study. especially if infection was at low infection rates, because dog with a possible double infection by $\mathrm{H}$. canis and Babesia sp could have generated only $H$. canis sequences in our analysis.

Results of the present study indicate $R$. sanguineus as the possible vector of $H$. canis in the State of Espirito Santo. Dogs in Brazil are generally found infested by $R$ sanguineus in urban areas, and by both Amblyomma spp and $R$. sanguineus in the rural areas (O'Dwyer et al., 2001: Szabó et al., 2001: Rubini et al., 2008), Most of the dogs sampled in the present study were from rural areas, where we found a high percentage of infection by $H$. canis in significant association with $R$. sanguineus infestations. We found no difference between the proportions of households with $H$. canis-infected dogs among rural and urban areas. This lack of significant difference could be related to the frequent occurrence of $R$. sanguineus in both the urban and rural areas, but also could be related to the smal number of urban households analyzed in the present study. Confirmation of the vector of canine hepatozoonosis in Brazil has been a controversial issue. One study in the State of Rio de Janeiro found significant association between $A$. cajennense infestations and the presence of $H$. canis gamonts in canine blood smears (O'D wyer et al. 2001). In addition, Amblyomma aureolatum was the only tick species that was found infesting $H$. canis-infected foxes in southern Brazil (Criado-Fornelio et al., 2006) Another study confirmed Amblyomma ovale to be the possible vector of $H$. canis in Rio de Janeiro, as demonstrated by experimental transmission and the finding of a naturally infected tick (For lano et al., 2005, 2007). On the other hand, several studies in Brazil have found infected dogs infested by both Amblyomma spp and $R$ sanguineus ticks (O'Dwyer et al., 2001: Rubini et al., 2008), $R$ sanguineus has been considered the main vector of $H$. canis in the Old World, where experimental transmission of the protozoa by $R$ sanguineus has been elegantly demonstrated (Baneth et al., 2001). Possibly, both $R$. sanguineus and a few Amblyomma species play a role in the transmission of $H$. canis in Brazil.

\section{Conclusion}

Canine hepatozoonosis caused by $\mathrm{H}$. canis appears to be a frequently occurring infection in areas where $R$. sanguineus is endemic. Since all infected dogs were found apparently healthy, the pathogenicity of $H$. canis for dogs in Espirito Santo remains unknown.

\section{Acknowledgments}

We are grateful to Denise M. Mancini [Coordenação Geral de Laboratórios de Saúde Pública (CGLAB). Secretaria de Vigilância em Saúde(SVS) do Ministério da Saúde (MS)], and Regina M. B. Terrão (Lacen Espírito Santo) for logistic support in Espirito Santo, and to the "Agentes Locais de Vigilância Ambiental em Saúde do Departamento de Vigilância Ambiental do Município de Nova Venécia, ES" for their valuable help during field work. This work was financially supported by the Fundaça de Amparo a Pesquisa do Estado de São Paulo (FAPESP grant 07/ 51899-2 to N.H.Y.), Coordenação de Aperfeiçoamento de Pessoal de Nivel Superior (CAPES PhD scholarship to M.G.S.) and Conselho Nacional de Desenvolvimento Científico e Tecnológico (CNPq career scholarship to M.B.L.).

\section{References}

Altschul, S.F., Gish, W., Miller, W., Myers, EW., Lipman, D.J. 1990. Basic local alignment search tool. I. Mol. Biol. 215, 403-410

Baneth, G., Weigler, B., 1997. Retrospective case-control study of hepatozoonosis in dogs in Israel. J. Vet. Int. Med. 11, 365-370.

Baneth, G., Samish, M., Alekseev, E., Aroch, L, Shkap, V., 2001. Transmission of Hepatozoon canis to dogs by naturally-fed or percutaneouslyinjected Rhipicephaius sanguineus ticks. J. Parasitol. 87, 606-611.

Baneth, G. Mathew, J.S., Shkap, V., Macintire, D.K., Barta, J.R., Ewing, SA 2003. Canine hepatozoonosis: two disease syndromes caused by separate Hepatozoon spp, Trends Parasitol. 19, 27-31.

Criado-Fornelio, A., Ruas, J.L. Casado, N., Farias, N.A, Soares, M.P., Müller, G. Brumt, J.G., Berne, M.E., Buling-Saraña, A., Barba-Carretero, J.C. 2006. New molecular data on mammalian Hepatozoon species (Apicomplexa: Adeleorina) from Brazil and Spain. J. Parasitol. 92, 93-99. Forlano, M., Scofield, A., Elisei, C., Fernandes, K.R. Ewing, S.A., Massard, C.L, 2005. Diagnosis of Hepatozoon spp. in Amblyomma ovale and its experimental transmission in domestic dogs in Brazil Vet Parasitol. $134,1-7$.

Forlano, M.D. Teixeira, K.R., Scofield, A. Elisei, C, Yotoko, K.S., Fernandes, K.R., Linhares, G.F., Ewing, S.A., Massard, C.I., 2007. Molecular characterization of $H$ eparozoon sp. from Brazilian dogs and its cular chatactefization of hepatazoon sp. from Brazilian dogs and it $145,21-30$.

Gavazza, A. Bizzeti, M., Papini, R., 2003. Observations on dogs found naturally infected with Hepatozoon canis in Italy. Rev. Med. Vet. 154, 565-571.

Gondim, F.P. Kohayagawa, A., Alencar, N.X., Biondo, A.W., Takahira, R.K. Franco, S.R.V., 1998. Canine hepatozoonosis in Brazil: description of eight naturally occurring cases. Vet. Parasitol. 74, 319-323.

Majláthová V. Hurníková, Z, Majláth, L., Petko, B, 2007. Hepatozoon canis infection in Slovakia: imported or autochthonous? Vector Canis infection in Slovakia: impor

Massard, CA., 1979. Hepatozoon canis (James, 1905) (Adeleida: Hepatozoidae ) em cães do Brasil, com uma revisảo do gênero em membros d ordem carnivora. Seropédica. Tese (Mestrado em Medicina Vetennánia-Parasitologia Veterinária. Departamento de Para

Mundim, A.V., Mundim, M.J.S., Jensen, N.M.P., Araujo, S.F., 1994. Hepatozoon caris: estudo retrospectivo de 22 casos de infecçăo natural em 10, 89-95.

Murata, T., Inoue, M., Taura, Y, 1995, Detection of Hepatozoon canis oocysts from ticks collected from infected dogs.J. Vet. Med. Sci. 75 $111-112$.

ODwyer, L.H., Massard, C.L. Pereira de Souza, J.C., 2001. Hepatozoon canis infection associated with dog ticks of rural areas of Rio de Janeiro State. Braz, Vet, Parasitol. 94, 143-150

Dyamada, M., Davoust, B., Boni, M., Dereure, J., Bucheton, B., Hammad, A. Itamoto, K., Okuda, M. Inokuma, H., 2005. Detection of Babesia canis rossi, B. canis vogeli, and Hepatozooncanis in dogs in a vil lage of eastern Sudan by using a screening PCR and sequencing methodologies. Clin, Diagn. Lah. Immunol. 12, 1343-1346.

Paludo, G.R., Friedmann, H., Dell'Porta, A, Macintire, D.K., Whitley, E.M. Boudreaux, M.K., Baneth, G., Blagburn, B.L, Dykstra, C.C, 2005. Hepo- 
tazoon spp, pathological and partial 185 rRNA sequence analysis from three Brazilian dogs. Parasitol. Res. 97, 167-170.

Rubini AS dos Sas Parast K. Ravalcan T. G Ribolla, P.E. ODw L.H., 2005. Molecular identification and characterization of canine Hepatazoon species from Brazil. Parasitol. Res, 97, 91-93.

Rubini, AS dos Santos Paduan, K Von Ah Lopes, V O'Dwyer, LH, 2008. Molecular and parasitological survey of Hepatozoon caris (Apicom- plexa: Hepatozoidae) in dogs from rural area of Sao Paulo state, Braz. Parasitol. Res, 102, 895-899.

Szabó, M.P., Cunha, T.M., Pinter, A. Vicentini, F., 2001. Ticks (Acari: lxodidae) associated with domestic dogs in Franca region, São Paulo. Braz, Exp. Appl. Acarol. 25, 909-916.

Vincent-Johnson, N.A., 2003. American canine hepatozoonosis. Vet. Clin. N. Am. Small Anim. Pract. 33, 905-920. 